\title{
Farmer adoption of sustainable intensification technologies in the maize systems of the Global South. A review
}

\author{
Eliot Jones-Garcia $^{1,2,3} \cdot$ Vijesh V. Krishna ${ }^{3}$ (D) \\ Accepted: 23 November 2020 / Published online: 8 January 2021 \\ (C) The Author(s) 2021
}

\begin{abstract}
This paper reviews the empirical literature on the determinants of farmer adoption of sustainable intensification technologies in maize agri-food systems of the Global South. The attributes of the technology and the dissemination institutions interact with farm/farmer-specific variables, leading to heterogeneous impacts, making the prediction of technology adoption challenging. However, most empirical studies oversimplify the adoption process and examine only the farm/farmer-specific variables as the determinants of adoption, thereby limiting the scope of learning on how the attributes of the technology and the dissemination system could have been altered to realize a more efficient and more inclusive technological change. We argue for a realignment of empirical adoption analysis for better implications through a conscious rejection of the assumption that the onus of technology performance rests solely with the farmer. Here we review the studies published between 2007 and 2018 on the adoption of sustainable intensification technologies in maize systems of the Global South to examine how the adoption models are currently dependent on the farm/farmer attributes vis-à-vis the attributes of technologies and disseminating institutions. The main findings from a synthesis of 137 adoption studies are threefold. (1) Limited information access and technologies not suitable for the small landholdings were the major constraints of farmer adoption of technologies. (2) The criticisms on the conventional adoption analysis concerning oversimplification and decontextualization of the decision-making process are reaffirmed. (3) The empirical adoption research needs to incorporate the attributes of technologies and the socio-institutional context to develop better research strategies toward inclusive agrarian development. We examine how the framework of the socioeconomic analysis can be reconstructed to facilitate the research and development (R\&D) institutions to overcome the major hurdles of rapid and inclusive dissemination. Evaluation of the degree to which the attributes of technology favor its adoption requires increased research attention.
\end{abstract}

Keywords Agricultural development · Technology diffusion · Maize agri-food systems · "Word Clouds" · Social inclusion

\section{Contents}

1 Introduction

2. Background: Recent Technological Changes in Maize Systems of the Global South

3. Methodology

4. Results and Discussion

Vijesh V. Krishna

v.krishna@cgiar.org

1 The Horizon Centre for Doctoral Training (CDT), University of Nottingham, Nottingham, UK

2 Future Food Beacon, University of Nottingham, Nottingham, UK

3 International Maize and Wheat Improvement Centre (CIMMYT), Texcoco, Mexico
4.1 Determinants of SIA Adoption: Who is Included and Who is Left Behind?

4.2 The Scope and Limitations of the Current Approach to Studying SIA Adoption

4.3 The Potential of Qualitative Methodology in Assessing Technology Change

5. Conclusion

Declarations

References

\section{Introduction}

The sustainable intensification of agriculture (SIA), "a process or system where agricultural yields are increased without adverse environmental impact and without the conversion of additional non-agricultural land" (Pretty and Bharucha 
2014), has emerged as an important strategic intervention for climate adaptation, agrarian development, and rural food security. The SIA paradigm includes a multitude of technologies, such as judicious use of chemical fertilizers, improved crop cultivars, soil and water conservation measures, intercropping, crop rotations, and Conservation Agriculture (Haile et al. 2017). Providing smallholders with greater access to SIA technologies is widely perceived as essential to increasing system productivity, sustainability, and resilience in the Global South. The development and the implementation of these technologies, however, are often criticized for incomplete theories of change (Loos et al. 2014; Struik and Kuyper 2017). Researchers question whether a technology can be considered truly sustainable if its key sociopolitical and cultural effects are ignored (Garnett and Godfray 2012; Mahon et al. 2017). Empirical analyses on the diffusion of SIA technologies have great potential against this context, to complement the biophysical impact studies conducted by agronomists and farming system experts by shedding light on the social, political, and economic dimensions.

In this paper, we postulate that through effectively capturing the determinants of the SIA technology adoption, researchers could contribute toward social sustainability by ensuring that the technological change is inclusive of the poor and the socially marginalized. The conventional technology dissemination process in the Global South generally favors large and wealthy farmers and is less effective in addressing the needs and preferences of the poor and the marginalized, who need these technologies the most. This InnovativenessNeeds Paradox, as described by Rogers (1962), stems from a lack of technology targeting and would result in increased economic inequality in rural areas and prevent achieving the stated goals of research and development $(R \& D)$ interventions. The importance of technology targeting for poverty alleviation is increasingly recognized these days (e.g., Lybbert et al. 2018). One such targeted technological intervention is depicted with the help of a photograph in Fig. 1, which shows women farmers of Eastern India being trained to use agricultural machinery for weed management in maize.

Ideally, the socioeconomic studies could contribute toward inclusive agrarian development by documenting the performance of technologies among the poor and the socially marginalized and by deriving valuable lessons on constraints and enabling factors of technology targeting. However, there exist several bottlenecks in the conceptual and empirical framework of current adoption studies, greatly reducing their relevance and scope (Brown et al. 2017; Doss 2006; Glover et al. 2016, 2019). Brown et al. (2017) showed that adoption studies largely ignore the necessity for a definitive "adoption" concept, with no indication of the extent or length of the technology use. Glover et al. $(2016,2019)$ extended this critique, stating that conventional analysis considers adoption as a largely individual, natural progression. New technologies are recognized as innately superior to the current means of production, and potential adopters as solely economically driven subjects. This framework ignores the intricate social, cognitive, epistemological, institutional, and cultural fabric that underlies decision-making. Willock et al. (1999), Borges et al. (2015), and Dessart et al. (2019), among others, showed that empirical researchers tend to focus on a decision the farmer should have been made, that is, choosing a technology that maximizes profit over the existing methods. Au contraire, farmers act based on a heterogeneous and complex set of incentives, irrespective of the economic gain, including environmental enhancement, personal integrity, and high ethical standards.

Furthermore, farmer adoption of technologies is popularly modeled in the literature using the binary concept of adoption. However, in reality, adoption comprises a range of farmers' choices from (a) immediate and continuous adoption of all technology components on the whole farm (or at least on all relevant crop plots) to (b) non-adoption of any technology component (Supplementary Materials, Fig. S1). The continuum shows that although capturing adoption in binary form is useful for impact evaluation, this approach greatly reduces the available information on the adoption process and its multiple dimensions.

In this paper, we put forward another criticism; most empirical adoption studies do not have the potential to contribute toward policies for inclusive development due to poor choice of explanatory variables. Several factors related to farm households, agroecological conditions, farming community, and technology itself could influence the transferability and uptake of SIA technologies. Farmer adoption of technologies cannot be fully explained in the absence of these variables and their interactions. This paper finds that there is excessive dependence on data concerning farm/farmer attributes to explain adoption. Socioeconomic research that can effectively address the question, "how can technology and dissemination system characteristics be adapted to increase the reach among the poor and the marginalized?", is highly valuable for both the R\&D and the policymakers alike. We review the current practices, explain the necessity to contextualize technological change, and suggest an alternative narrative of adoption for the applied research.

The extent of decontextualization and oversimplification of the adoption process is linked intrinsically to the chosen analytical approach. Adoption analysts have conventionally used the classification or sorting models, such as logistic (or logit) and probit models. These models were developed in the first half of the twentieth century (Bliss 1934; Berkson 1944) and started attracting research interest in the 1970s (Zopounidis and Doumpos 2002). For an introduction of probit, logistic, and other limited dependent variable models, one may refer to the standard econometric textbooks such as Maddala (1986) and Wooldridge (2020). Soon, researchers started using these 
Fig. 1 Sustainable intensification in practice. Women farmers being trained on weed management and intercultural operations using "power weeder" in maize plots in Odisha, India. Power weeder is a machinery, emerging in popularity among farmers, for weeding and earthing-up for spring maize cultivated in this region's red and lateritic soils. Photo by Dr. Wasim Iftikar, CIMMYT (India)

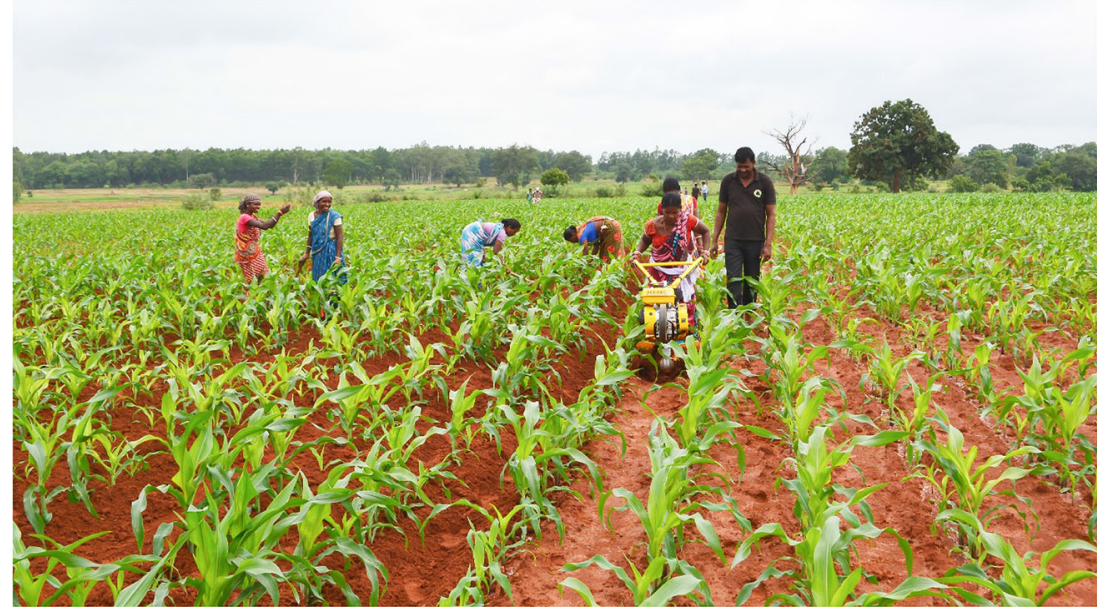

models to examine the determinants of technology adoption. For example, the probit model was used to predict varietal diffusion in maize in Kenya as early as 1975 (Gerhart 1975). This practice still dominates empirical adoption studies in agriculture. Alternatively, the extent of adoption or adoption intensity can be modeled using a Tobit regression framework, which was developed by Tobin (1958) to capture censored continuous outcome variables (e.g., the share of farmland area with a given technology, which is a variable with lower and upper limits of detection at 0 and 100\%; e.g., Sinyolo (2020)). Count data models, such as Poisson or negative binomial regression, are used to capture farmer adoption of individual components of a technology portfolio (i.e., adoption intensity) or adoption of multiple complementary technologies in agriculture (Gido et al. 2015; Krishna et al. 2015; Mahama et al. 2020). Extensions of binary variable models, such as multivariable probit/logit and multinomial logit, are used to capture the adoption complementarities between multiple technologies (Kassie et al. 2015; Wainaina et al. 2016). Duration models are used, although rarely, to capture the temporal dimension of adoption (Matuschke and Qaim 2008; Ofori et al. 2020). Irrespective of the model selection, when an adoption study frames its research questions in order to fit the available econometric framework, most of the contextual information is lost in the process, and the study fails to contribute effectively toward policy development.

The prevalence of micro-level empirical adoption studies' limitations - oversimplifying the adoption process, neglecting the dynamic nature of the adoption decision, and decontextualization - are assessed alongside their implications through a systematic review of SIA adoption literature in maize production systems of the Global South. The SIA has become a focal point of R\&D initiatives in maize agri-food systems, especially in sub-Saharan Africa (SSA), where maize contributes to about $50 \%$ of calorie consumption in several rural communities (Lunduka et al. 2019). Even in parts of the world where maize is not used for human consumption, the crop has high economic relevance, contributing to biofuel, meat, and dairy industries (Tanumihardjo et al. 2020). As such, there is a general concern that SIA might be used to justify the accelerated adoption of unsustainable forms of high-input, hi-tech agriculture to satisfy increased demand (Godfray 2015). Due to the abundance of publications, the socioeconomic literature on technological change in maize could become an ideal microcosm to explore the scope and limitations of contemporary adoption analysis. We limited the search to papers published between 2007 and 2018. The study will explore the typical estimation patterns and derive the individually proven most valuable predictors of adoption probability and intensity of adoption. Further, the uptake of SIA technologies and the major constraints to their wider diffusion will be examined to design a more inclusive paradigm of agrarian development.

The following section introduces a short history of technological change in maize systems over the last two decades. Section 3 details the methodology followed in the study selection and analysis. The key findings from the systematic review are presented and discussed in Section 4. Finally, Section 5 concludes the study and provides specific recommendations for enhancing the value of adoption analysis for $\mathrm{R} \& \mathrm{D}$ interventions.

\section{Background: recent technological changes in maize systems of the Global South}

Maize is a crop of high economic importance in most tropical countries, which are also home to a large share of the global population living in poverty. Maize production is facing several abiotic and biotic constraints. Heat and drought, as well as changing patterns of precipitation, are already recognized as the main reasons for poor maize harvests (Tesfaye et al. 2018). Overall, the atmospheric temperatures are predicted to rise by 2.1-3.6 ${ }^{\circ} \mathrm{C}$ by 2050 , which will have devastating 
consequences for crop production in general and maize in particular (Cairns et al. 2012; Lunduka et al. 2019). During drought years, with up to a $40 \%$ reduction in water availability, maize yields are found to reduce by $39 \%$ (Daryanto et al. 2016). Extreme weather conditions also increase the seasonal fluctuations of food availability and thus have adverse impacts on poor consumers (Haile et al. 2017). In conjunction with the increased risk of abiotic stress, many biotic factors are gaining prominence over time. One of the major examples is the fall armyworm (FAW; Spodoptera frugiperda J.E. Smith), the recent outbreak of which has significantly reduced maize productivity and adversely affected farmers' livelihoods in African and Asian countries (Kassie et al. 2020). In Kenya, for example, the FAW has gained the status of a major pest, reducing the annual maize grain production by about 1 million tons (de Groote et al. 2020).

During the last two decades, the R\&D investment in the intensification of maize systems has been steadily increasing, which has resulted in a consistent flow of technological interventions (Krishna et al. 2019b). During 2008-2017, maize agri-food systems attracted a large flow of research funds, with projects like Sustainable Intensification of MaizeLegume Cropping Systems for Food Security in Eastern and Southern Africa (SIMLESA; http://simlesa.cimmyt.org/) and Drought Tolerant Maize for Africa (DTMA; http://dtma. cimmyt.org/). Possibly due to these interventions, alongside improvement in the quality of agricultural input and an increase in the quantity of inputs applied per unit of land, maize production has increased over time in the leastdeveloped nations. More importantly, this has occurred despite the mounting threat of changing climate and the increasing incidents of insect pests and diseases. The total maize production in these countries has doubled during the period 2000-2018 and continues to grow steadily. The growth rate of maize grain production has been significantly higher than that of maize acreage, indicating a consistent improvement in productivity (Supplementary Materials; Fig. S2). Farmer adoption of different intensification technologies in maize is linked to increased crop yield, profitability, or both, resulting in increased household income and consumption (Abdulai 2016; Chepchirchir et al. 2017; Makate et al. 2017).

Breeding for improved and stress-tolerant crop varieties has been a key strategy of the intensification of maize systems to increase yield potential and reduce yield losses (Cairns and Prasanna 2018, Shiferaw et al. 2011). In 2018, more than 50\% of CGIAR maize innovations involved germplasm-based research (CGIAR 2018). Contrary to other staple crops like wheat and rice, maize is cross-pollinated. Despite having logistical limitations to producing and delivering genetically uniform varieties (Morris et al. 2003), maize breeders have managed to develop hybrid and open-pollinating varieties with desirable traits to cope with several biotic and abiotic stresses, some of which are discussed below. The possibility of generating hybrid vigor has resulted in increased involvement of private maize seed producers, supported by the structural adjustment in line with market liberalization in lowincome countries (Erenstein and Kassie 2018).

Along with yield improvement, reducing yield loss from abiotic and biotic stresses has gained significant strategic importance in maize breeding. Drought- and heat-tolerant maize varieties, first developed in the 1990s, have been sustaining farmers' livelihoods during cropping seasons with lower rainfall or increased temperatures or both (Lunduka et al. 2019). Makate et al. (2017) indicated that the adoption of droughttolerant varieties increased maize yield by $15-22 \%$ in Zimbabwe, while Wossen et al. (2017) indicated a $13 \%$ yield increase in Nigeria. Amondo et al. (2019) observed similar positive effects in Zambia.

Maize breeding also aims to enhance the nutritional intake of rural households. Nutrient deficiency is a major cause of infant mortality, morbidity, and stunting across much of the Global South (de Groote et al. 2016). Consumption of nutritious and diverse foods is limited due to high prices (especially in market-oriented food systems) and poor crop-growing conditions (especially in subsistence systems). Genetic biofortification is the process of breeding plant varieties to contain higher levels of certain nutrients. Biofortified maize (e.g., quality protein maize, QPM) varieties were developed to combat protein deficiency among children in SSA and parts of South Asia (de Groote et al. 2014) and to reduce the dependence on synthetic amino acids for poultry feeds in South Asia (Krishna et al. 2014). However, many studies have demonstrated that the economic potential of QPM is low (Krishna et al. 2014; de Groote et al. 2016; Gunaratna et al. 2019).

Over the last two decades, the R\&D investment in maize production systems has diversified the innovation portfolio instead of focusing on breeding for improved varieties. System intensification with injudicious use of external inputs is known to reduce cropping diversity and contribute toward soil deterioration (Wainaina et al. 2016). The high cost and increased vulnerability of the production process and the associated financial burden often draw profits out of the farming community and weaken the efforts aimed at preserving local maize species and indigenous farming practices (Gunton et al. 2016; Struik and Kuyper 2017; Snapp et al. 2018; Glover et al. 2019). In response, several system-focused low-input technologies have emerged, centered on the resilience of smallholder communities. For example, through relying on minimum tillage and maintaining a soil cover with crop residues, Conservation Agriculture has emerged as a key intervention to reduce production cost and financial vulnerability of smallholders (Montt and Luu 2020; Ntshangase et al. 2018). Another critical intervention is crop diversification, in which maize is combined with other crops, often a leguminous crop that can fix nitrogen in the soil and enrich protein consumption for poor rural households (Kamanga et al. 2014; Yap et al. 
2017). Technologies of this nature sustain and contribute to rather than degrade the household's natural resource base. Such interventions have simultaneously facilitated higher maize and legume production in Africa (Mekuria et al., 2017).

Another group of promising SIA practices is integrated pest and weed management (IPWM). Herbicides are conventionally known to be a useful tool for controlling invasive weed species (Vommi et al., 2013). Herbicide-tolerant maize varieties have facilitated significant cost savings by allowing weed control in the growing season with reduced dependence on hired labor (Alwang et al. 2019). In the integrated approach, pest and weed infestations are addressed through not one but several interventions (e.g., resistant varieties, seed treatment, crop rotations, introducing predator species, and natural enemies into a production system) (Jayasooriya and Aheeyar 2016). During the recent outbreak of the FAW in Africa and Asia, IPWM has been widely recommended as the most effective intervention (FAO, 2018; Prasanna et al., 2018). However, the success of IPWM in maize farming has been hard to measure or quantify (Renkow and Byerlee, 2010). While some studies suggested that the adoption of IPWM had a positive impact on yield and farmers' health, these examples remain isolated and in small numbers (Murage et al., 2015).

The above discussion indicates that there was no shortage of innovations for the maize systems of the Global South during the last two decades. While adoption has been widespread for some SIA technologies, leading to greater yields and farmer welfare, many innovations came and went without farmers noticing or benefiting them. At the same time, more than 800 million people remain undernourished across the world (FAO 2019), a significant share of which depends on maize for subsistence consumption and income. Increasing the adoption of promising SIA technologies can be done by remodeling the dissemination system and making the necessary changes in the agrarian policies, for which a systematic analysis of adoption would be enormously helpful.

\section{Methodology}

The determinants and impacts of the on-farm adoption of SIA technologies form one of the well-published fields of agricultural sciences. Empirical studies have appeared in a wide range of peer-reviewed journals, books, and gray literature (e.g., working papers). For this review, we draw evidence primarily from a set of well-established scientific and economic databases, as depicted in Fig. 2. The objective of the literature search was to obtain recently published studies conducted in the maize cultivation systems of the Global South and intended to explain the differential adoption of technologies within the selected farming communities. To ensure quality and comprehensiveness in the literature search, the guidelines of PRESS (Peer Review of Electronic Search Strategies (Mcgowan et al. 2016)) and PRISMA (Preferred Reporting Items for Systematic reviews and Meta-Analyses (Moher et al. 2009)) were meticulously followed.

The literature selection process was completed in two stages. In the first stage, studies for inclusion in the review were identified through keyword searches. We identified the search terms iteratively. As the first step, a simple search with "(maize OR corn) AND 'technology adoption"” was performed. Using the insights from this search, additional keywords were identified and included, and the detailed search was performed with "(maize OR corn) AND (farmer OR smallholder OR household) AND ('technology adoption' OR 'adoption of technology' OR 'adoption of technologies' OR ‘adoption of innovation' OR ‘innovation adoption').” We have also tried proximity searching and truncation (with an asterisk symbol to search for different word endings) while working with some of the databases. The search covered both peer-reviewed and gray literature but was limited to the manuscripts published between 2007 and 2018. It was anticipated that this 12-year period would yield an extensive number of publications due to the increased international R\&D investment for more sustainable maize systems. The primary search yielded 17,676 papers from various journals and gray literature, but most were found irrelevant to meet the search objective. A total of 3376 titles and abstracts were screened for eligibility. Only the studies that empirically estimated technology adoption in smallholder maize production sectors were included. This selection was not conditional on whether data was collected at plot, individual, or household level. Studies that were used as a precursor to an impact assessment were included, which was further refined to only the studies with texts in the English language that had completed surveys in developing countries and had attempted to explain the differential adoption by farmers. The texts selected were ratified by both authors to maintain a consistent interpretation of what is (not) qualified as relevant textual evidence. A total of 196 texts were selected for the second stage examination.

The second stage of literature selection involved exploration of the reference lists of the 196 papers for studies that could have been missed in the first stage. This procedure was repeated until all reference lists were exhausted. The aim was to include papers published in lesser-known journals that still met the search objective. To avoid selection and publication bias, the selected studies included papers both in peerreviewed journals and in gray literature. However, if a report or working paper was later developed and published as a peerreviewed journal paper, we included only the latter to avoid repetition. Of these manuscripts that were reviewed in full, 152 were rejected for various reasons, as shown in Fig. 2. In these cases, studies were deemed methodologically relevant only if they explored the reasons for the differential adoption by farmers, for example, the quantitative studies that treated 
Fig. 2 Selection of studies for inclusion in the systematic review. The PRISMA flow diagram for selection and inclusion of studies in the systematic review detailing the database searches, the number of abstracts screened, and the full texts retrieved. * Other sources include the reference lists of the 196 studies, which were searched for eligibility and discussion with the researchers working in the field of adoption studies
Stage 1: Identification

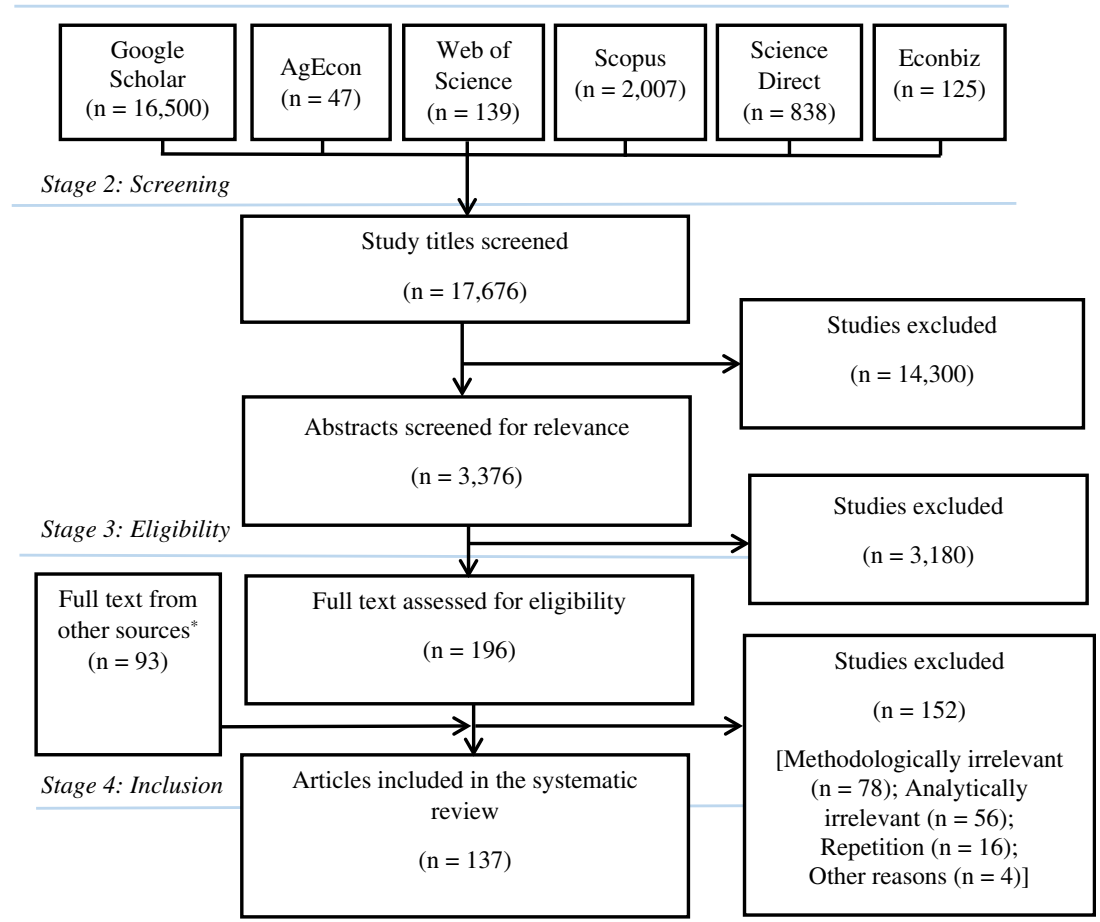

adoption as a dependent variable. The other reasons for exclusion include the lack of empirical data analysis or the lack of focus on technology. For example, due to the primary focus being on the intervening factors, such as gender and livelihood, some studies inadequately defined the adoption process. A total of 137 studies, the list of which is provided in the Supplementary Materials (Text 1), were qualified for inclusion in the final review. From them, study details (e.g., country of data collection, year of publication, year of data collection, sample size, and unit of observation), econometric models employed if any (e.g., logit and Poisson), and the names of dependent and explanatory variables (e.g., the share of adoption and education) were recorded in Microsoft Excel. The literature search and data entry were conducted during April-June 2019, and this dataset was verified to avoid omissions and errors in August 2019.

The statistical analysis of the data from the systematic review did not focus on the aggregate adoption rate of different technologies. Several of the reviewed studies designed their sampling frame in such a way that it ensured a certain minimum number of adopters for the analysis, which, although would facilitate a meaningful comparison of adopters and non-adopters, may not provide representative adoption rates for the region (Doss 2006). Hence, instead, we analyzed the data on key determinants of the adoption of technologies. Estimating the adoption determinants has been one of the major tasks of empirical microeconomic evaluation on technological change (Krishna et al. 2020). Here, we disregarded the unit of measurement while categorizing the determining variables and followed the conceptual clustering using descriptive concepts. For example, the level of education of farmers is measured as the number of years in school or an ordered scale but, since they represent the same concept, were put together. The definition of variables used for the clustering is provided in Supplementary Table S2. The variables that appeared statistically significant in regression models, which use a $t$ test or $z$ test for deriving the significance (depending on the model specification), are listed against the frequency of their appearance. In the next step, we constructed "Word Clouds" (Text Clouds or Tag Clouds) to visually examine and depict the prominence of explanatory variables in the adoption analyses, and for this, we used the wordcloud package in R (Fellows 2018). Word Clouds are found useful for the depiction of the frequency with which phrases and ideas appear in fields of research or textual responses (e.g., Kates (2011), Rohrer et al. (2017)). Here the letter size denotes the frequency with which the variable appears as significantly different from zero in the econometric models across the reviewed studies.

We further examined whether the type of intervention and study region determine the type of statistical model used. The technologies gathered from the literature search were classified broadly into three groups - seed-based technologies (e.g., hybrids, certified, and seeds), managerial or agronomic interventions (e.g., soil and water conservation and fertilizer use), and others (e.g., selection of marketing channels). The econometric models were also classified into three groups - models with a single binary dependent variable (e.g., simple logit), 
models with multiple interrelated binary dependent variables (e.g., multinomial logit), and non-binary dependent variable models (e.g., Poisson). We hypothesize that the characteristics of technology intervention determine the selection of econometric models. When technology is composite (e.g., Conservation Agriculture) and farmers could adopt some of the individual components, the researchers may have to estimate the intensity of adoption with respect to the number of components adopted on farm, instead of the probability of adopting the technology as a whole. Similarly, if one has to disentangle the different stages in the adoption process (e.g., awareness and experimentation), models having a single binary dependent variable will not be useful. However, there is no reason to expect that the study area would determine the econometric framework once we control for the type of intervention. To test the association between technology types and analytical model selection, we used multinomial logit or polytomous logistic regression model, in which the dependent variable is categorical with outcomes that have no natural ordering. The details of model assumptions and estimation of multinomial logit regression models are available in the literature (Greene 2018).

\section{Results and discussion}

Here we examine the determinants of technology adoption in maize systems to understand the social dimension of technological change (e.g., "who is left behind?") (Sub-section 4.1), and to assess the scope and limitations of the current approach in capturing the social dimension (Sub-section 4.2). Furthermore, the potential to employ qualitative methods to study the adoption process is explored (Sub-section 4.3). However, as a preamble to this synthesis, a brief description of the nature of the reviewed adoption studies is provided. Four prominent patterns are found interesting, which are depicted in Fig. 3a-d.

One, a drastic increase in the number of adoption studies. Before 2010, less than five adoption studies were published annually on technological change in maize. After 2015, however, the minimum number of papers published in any year was 15 (Fig. 3a). We will assess in the subsequent sections to see whether this proliferation enabled a better understanding of the technological change in the maize systems of the Global South.

Two, oversimplification of the adoption process. More than $50 \%$ of the studies assessed the binary nature of the adoption process, either in isolation (e.g., with logit model) or jointly with other managerial decisions (e.g., with multivariate logit) (Fig. 3b). One of the reasons for the high use of binary adoption variables is that a significant share of these studies (34\%) estimated adoption as a necessary precursor of impact evaluation. The problematic approach of treating adoption as a simple dichotomous process was raised by Feder et al. (1985), and the critique has persisted ever since (Bunclark et al. 2018; Glover et al. 2019).

Three, a high regional concentration of adoption studies. Most of the reviewed studies were conducted in Africa, particularly in Kenya and Ethiopia (2-3 studies published per year per country) (Fig. 3c). The high regional focus could be due to the targeted $\mathrm{R} \& \mathrm{D}$ investment that prompts research projects to focus on areas where maize production has high livelihood implications, and the research environment is congenial (Ouma et al. 2014; Mathenge et al. 2015). There has been a perceivable gap in understanding the constraints Asian and Latin American farmers face in maize production and marketing.

Four, an expansion of sample size over time. During 2007 2008, about 300-400 observations were included per adoption analysis. During 2017-2018, however, the average sample size increased to more than 1000 observations (Fig. 3d). The increased sample size is expected to have significant implications on both analytical rigor and the generalizability of the observed patterns. An increase in both number of publications per year and the sample size indicates increasing investment in socioeconomic research in maize in Africa. The effects of this phenomenon on policy formulation, however, remain unclear.

We found that in the adoption literature, five individual technologies have been popularly studied (Fig. 4a). Varietal improvement is the most popular technology, and this was studied in more than 60 papers. The adoption of chemical fertilizers and soil and water conservation technologies was the topic of empirical investigation in 44 studies and 40 studies, respectively. The other major technologies were Conservation Agriculture and organic manure application. The change in the prominence of the technologies in adoption studies over the years is shown in Fig. 4b. While there has been a marked decline in the prominence of chemical fertilizers and no big changes in that of improved varieties in the adoption literature, the natural resource conservation technologies have been growing in academic popularity. The possible reasons behind this pattern are provided in the Stripe Review of Social Sciences in the CGIAR (CGIAR Science Council 2009).

We further examined whether the type of technological interventions determines the econometric approach used in the adoption studies. The technologies were classified into seed-based, managerial or agronomic, and others. The researchers used one of the three groups of econometric approaches in adoption analysis - single/independent binary dependent variable models, models with multiple interrelated binary dependent variables (MIBDV), or single/independent 

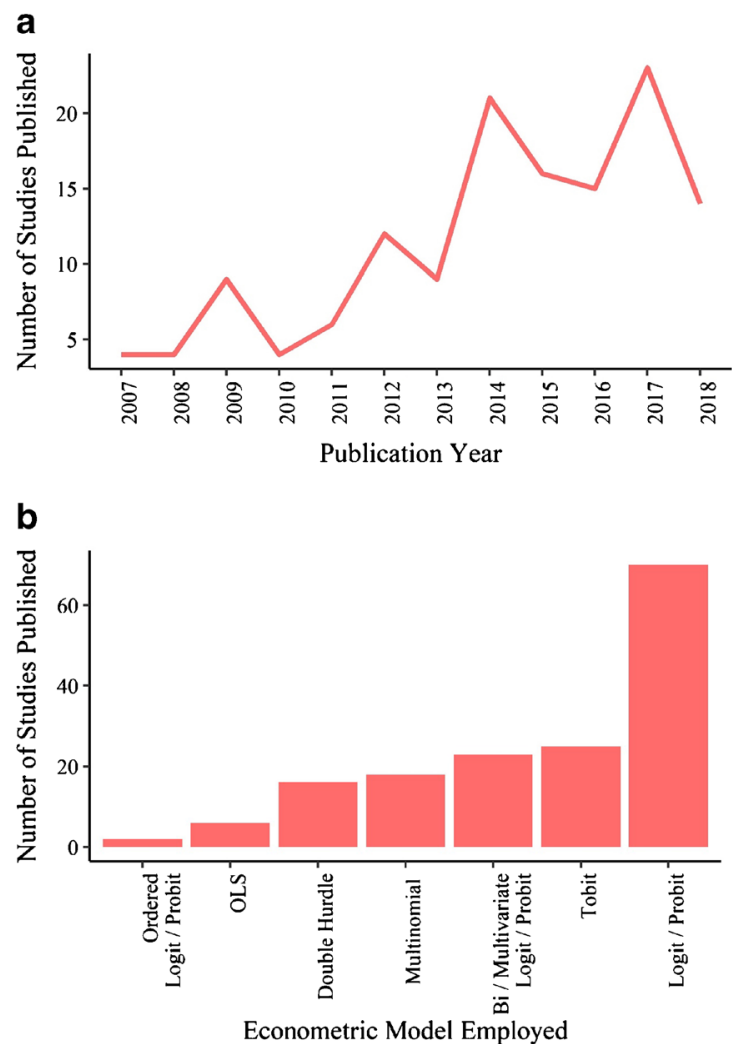

Fig. 3 Characteristics of adoption studies included in the systematic review (2007-2018). a Publication year, b econometric model employed, c study countries and number of studies published (20072018), and $\mathbf{d}$ mean sample size (number of observations) by year of
C

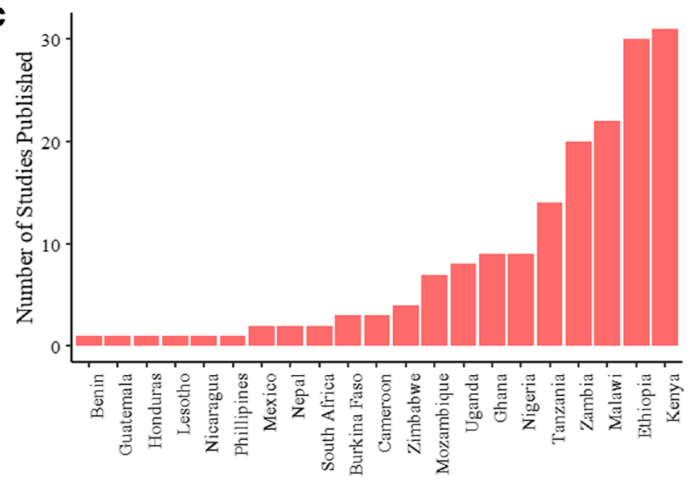

d

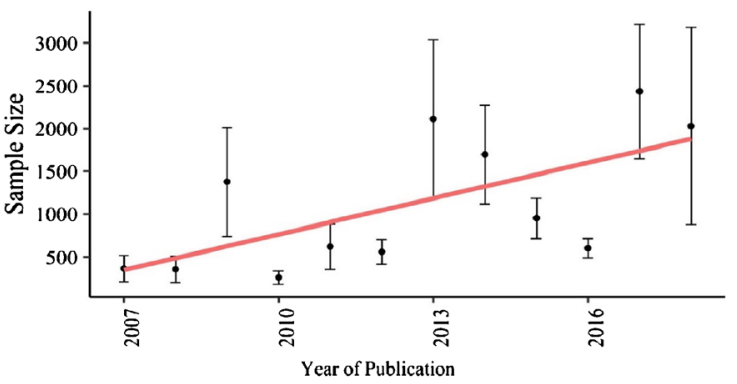

publication. Number of observations $=137$. In panel $\mathbf{d}$, in the vertical axes, the sample size (number of households) is provided, and the error bars represent the standard error of the mean sample size, and the red line indicates the linear trend in time non-binary dependent variable models. From the 137 reviewed studies, we obtained 357 models for examination (i.e., 2.6 models per study). The Pearson $\chi 2$ test showed that the type of econometric models used in a study is strongly associated with the type of interventions addressed (Table 1). Technologies under the managerial or agronomic category were evaluated more frequently than seed-based and other technologies in all three model categories. However, the MIBDV models were particularly popular to study the adoption of managerial interventions (Table 2). One of the possible reasons is the composite nature of these interventions, comprising several individual components, of which a large share of farmers adopts only a few. A typical example is Conservation Agriculture, which comprised three components - permanent soil cover by crop residues or cover crops, direct planting of crops with minimum soil disturbance (no-till), and crop rotation (Pittelkow et al. 2015). Farmers often adopt one or more of these components due to various reasons, including the constraints to accessing complementary inputs (Giller et al. 2015). The adoption analyses of
Conservation Agriculture use models to account for the adoption of technology components. For example, Tambo and Mockshell (2018) examined farmer adoption of Conservation Agriculture in maize in SSA using the multinomial logit regression framework, as only a minority adopted all three components in combination.

Table 2 also shows that, over the years, the use of models with MIBDV gained prominence in adoption literature. On the other hand, the use of models with single non-binary dependent variables was declining. Technically, these models can also be used to analyze adoption intensity. However, the advantage of MIBDV is that one can trace out the reasons for the non-adoption of a given technology component, and this is not possible with the single-equation models, such as Poisson regression models.

The reviewed studies that estimated adoption models as the first stage of impact assessment were mostly dependent on (single or multiple) binary dependent variable regression models (Table 2). This pattern is unsurprising as there is an array of econometric models, such as treatment-effect models, 
Fig. 4 Technologies examined in the adoption studies during 2007 2018. a Technologies assessed in the reviewed studies and $\mathbf{b}$ relative importance of technologies studied over time a

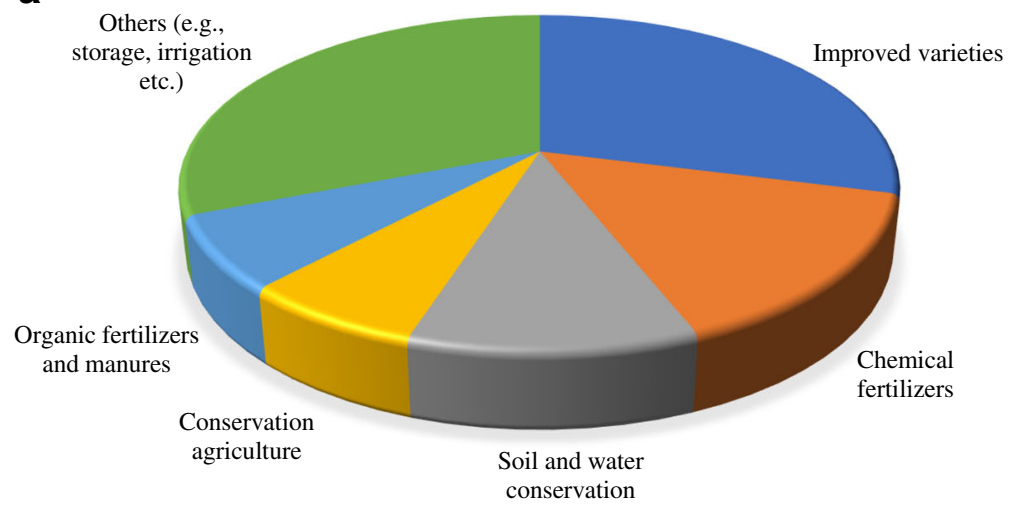

b

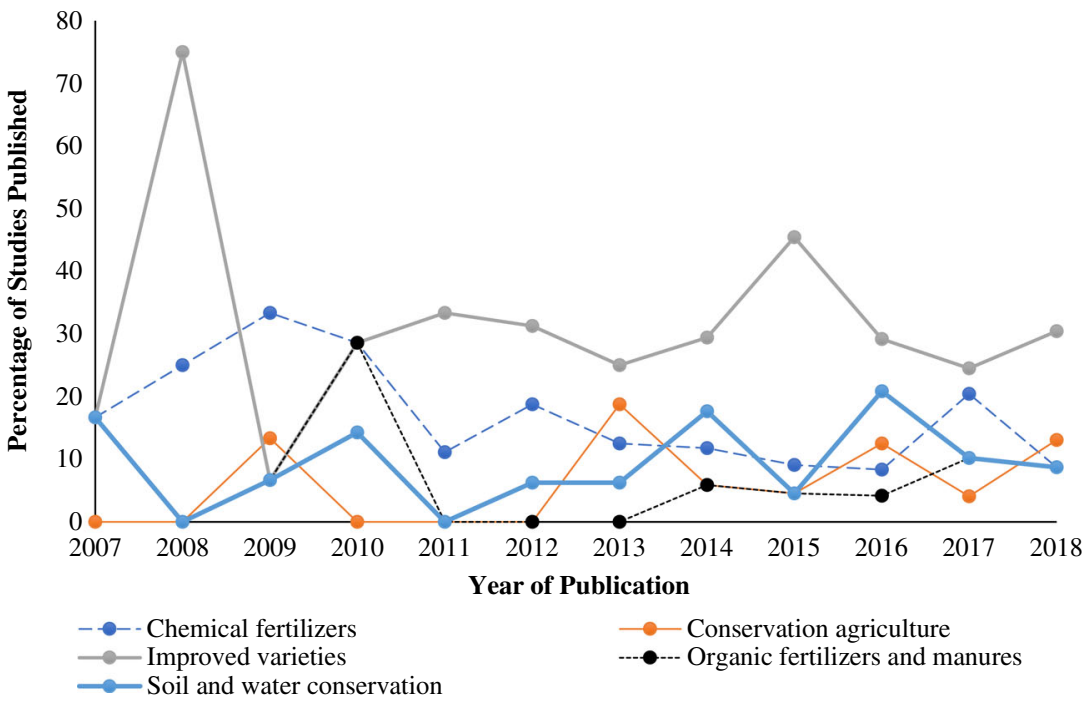

which require technology adoption to be estimated as a binary variable (Wooldridge 2003; Diagne and Demont 2007; Loevinsohn et al. 2013). Finally, we also found that the selection of the econometric framework varies based on the study country (e.g., studies conducted in Ethiopia use MIBDV models). Socioeconomic researchers working on maize
Table 1 Relationship between the type of intervention examined and the econometric model estimated

\begin{tabular}{|c|c|c|c|c|c|}
\hline \multirow[t]{2}{*}{$\%$ of row totals } & & \multicolumn{3}{|c|}{ Type of interventions } & \multirow{2}{*}{$\begin{array}{l}\text { Row } \\
\text { total }\end{array}$} \\
\hline & & $\begin{array}{l}\text { Seed- } \\
\text { based }\end{array}$ & Agronomic & $\begin{array}{l}\text { Others (e.g., } \\
\text { storage) }\end{array}$ & \\
\hline \multirow{3}{*}{$\begin{array}{l}\text { Type of } \\
\text { econometric } \\
\text { models: }\end{array}$} & Single binary dependent variable & 35.10 & 56.87 & 8.03 & $\begin{array}{l}100.00 \\
(n=122)\end{array}$ \\
\hline & $\begin{array}{l}\text { Multiple interrelated binary } \\
\text { dependent variables (MIBDV) }\end{array}$ & 15.61 & 82.64 & 1.75 & $\begin{array}{l}100.00 \\
(n=144)\end{array}$ \\
\hline & Non-binary dependent variable & 37.03 & 60.77 & 2.20 & $\begin{array}{l}100.00 \\
(n=91)\end{array}$ \\
\hline Overall & & 24.00 & 72.62 & 3.39 & $\begin{array}{l}100.00 \\
(n=357)\end{array}$ \\
\hline
\end{tabular}

The percentage of row totals is shown in the table. The number of observations of the individual models is used as the analytical weight. Here, $n$ represents the number of econometric models in each category. Pearson $\chi 2$ test statistic for the independence of the rows and columns $(\mathrm{df} .=4)$ is $3.2 \mathrm{E}+04[p \leq 0.00]$, indicating that the association between the type of intervention and the type of econometric model used for estimation is statistically significant 
Table 2 Determinants of estimation framework for quantitative adoption analysis

Multinomial logit coefficients (std. error)

\begin{tabular}{|c|c|c|c|}
\hline & \\
\hline & Model 1: $\frac{\text { MIBDV }}{\text { Single binary var. }}$ & Model 2: $\frac{\text { Non-binary var. }}{\text { Single binary var. }}$ & Model 3: $\frac{\text { Non-binary var }}{\text { MIBDV }}$ \\
\hline \multicolumn{4}{|l|}{ Type of interventions (reference: seed-based) } \\
\hline Agronomic & $\begin{array}{c}0.980^{* * * *} \\
(0.312)\end{array}$ & $\begin{array}{r}-0.284 \\
(0.333)\end{array}$ & $\begin{array}{c}-1.264^{* * * *} \\
(0.345)\end{array}$ \\
\hline Others & $\begin{array}{l}-0.167 \\
(0.723)\end{array}$ & $\begin{array}{c}0.353 \\
(0.615)\end{array}$ & $\begin{array}{c}0.520 \\
(0.780)\end{array}$ \\
\hline Publication year & $\begin{array}{c}0.301^{* * * *} \\
(0.055)\end{array}$ & $\begin{array}{c}-0.083^{*} \\
(0.050)\end{array}$ & $\begin{array}{c}-0.384^{\text {**** }} \\
(0.061)\end{array}$ \\
\hline Adoption analysis for impact estimation ( $1=$ yes; 0 otherwise $)$ & $\begin{array}{l}-0.119 \\
(0.323)\end{array}$ & $\begin{array}{c}-1.203^{* * * *} \\
(0.360)\end{array}$ & $\begin{array}{c}-1.084^{* * * *} \\
(0.384)\end{array}$ \\
\hline \multicolumn{4}{|l|}{ Country dummies ${ }^{\#}$ (reference: other countries taken together) } \\
\hline Ethiopia & $\begin{array}{c}1.338^{* * * *} \\
(0.396)\end{array}$ & $\begin{array}{c}0.002 \\
(0.444)\end{array}$ & $\begin{array}{c}-1.336^{* * * *} \\
(0.420)\end{array}$ \\
\hline Kenya & $\begin{array}{c}0.078 \\
(0.354)\end{array}$ & $\begin{array}{c}-1.007^{* * *} \\
(0.416)\end{array}$ & $\begin{array}{c}-1.085^{\text {**** }} \\
(0.430)\end{array}$ \\
\hline Tanzania & $\begin{array}{c}0.402 \\
(0.521)\end{array}$ & $\begin{array}{c}0.390 \\
(0.578)\end{array}$ & $\begin{array}{r}-0.012 \\
(0.555)\end{array}$ \\
\hline Malawi & $\begin{array}{l}-0.064 \\
(0.394)\end{array}$ & $\begin{array}{r}-0.353 \\
(0.417)\end{array}$ & $\begin{array}{r}-0.289 \\
(0.443)\end{array}$ \\
\hline Zambia & $\begin{array}{c}0.389 \\
(0.445)\end{array}$ & $\begin{array}{l}0.720 \\
(0.477)\end{array}$ & $\begin{array}{c}0.331 \\
(0.455)\end{array}$ \\
\hline Nigeria & $\begin{array}{c}-1.220 \\
(0.959)\end{array}$ & $\begin{array}{r}-0.406 \\
(0.690)\end{array}$ & $\begin{array}{c}0.815 \\
(1.091)\end{array}$ \\
\hline Model intercept & $\begin{array}{c}-606.025^{* * * * *} \\
(110.621)\end{array}$ & $\begin{array}{c}167.962^{* * * *} \\
(100.882)\end{array}$ & $\begin{array}{c}773.987^{* * * *} \\
(122.104)\end{array}$ \\
\hline
\end{tabular}

MIBDV stands for models with multiple interrelated binary dependent variables. The dependent variable in the multinomial logit is the relative probability of occurrence of a variable to the base outcome. For example, model 1 captures the relative probability of estimating an econometric model with MIBDV to that for a single binary dependent variable. ${ }^{* * *} p \leq 0.01 ;{ }^{* * *} p \leq 0.05 ;{ }^{*} p \leq 0.10$. ${ }^{*}$ Tested for joint significance. $\chi 2$ test statistic (df. 12) is $28.95[p \leq 0.01]$. Model statistics: log-likelihood ratio, -327.25 . LR $\chi 2: 117.74[p \leq 0.00]$

technology adoption form a small, interconnected group who repeatedly use certain modeling approaches.

\subsection{Determinants of SIA adoption: who is included and who is left behind?}

The social dimension of sustainable intensification has multiple aspects (such as labor rights, animal welfare, social inclusion, and equity), but they are rarely examined, as indicated by Garnett and Godfray (2012). Through this adoption review, we examine the social inclusiveness of SIA R\&D interventions. Often, the adoption studies, not only those concerning maize, attribute non-adoption or dis-adoption of technology solely to farm households' characteristics. A farmer's lack of education and awareness, the small size of the farm, and the sex and ethnicity of the household head are shown as preventing them from adopting the otherwise promising technology. These studies rarely discuss how the characteristics of the technology and the dissemination approaches should have been modified to cater to the heterogeneous demands from farmer groups, such as marginal and small farmers, women, and illiterates. Against this background, we analyzed the adoption literature on the SIA of maize systems by deviating from the conventional line of interrogation of "who is adopting the technology" to "who is excluded from the technology interventions." Such a change in perspective has high significance; several farmer households do not voluntarily become non-adopters and dis-adopters, but their socioeconomic environment does not facilitate adoption.

The most important determinants of adoption frequency and intensity of SIA technologies are shown in a Word Cloud (Fig. 5a). Further variable details are given in Supplementary Tables S1 and S2. Access to information about farming was one of the most frequently used variables, appearing statistically significant in $64 \%$ of the studies, followed closely by landholding size $(55 \%)$, farmer's age (53\%), and education (51\%). Figure $5 \mathrm{~b}$ and c show the relative importance of variables as determinants of adoption probability (e.g., farmer adopted/did not adopt the technology on- 
Fig. 5 Statistically significant determinant variables. a Of both probability and intensity, $\mathbf{b}$ of adoption probability, and $\mathbf{c}$ of adoption intensity. We used wordcloud $\mathrm{R}$ package to visualize the variables that frequently appear in the adoption studies as statistically significant. The sample size was used as the analytical weight. The larger the letter size, the more frequently a variable appears in the econometric models as a statistically significant determinant of farmer adoption. For example, the variable "information access' appears as the most prominent one in panel a as it was significant in 89 adoption models. In contrast, the variable "kinship" appeared significant in only 20 models, hence in smaller font. The font colors do not have any statistical relevance. The data on the frequency of variables used in the models and the number of times these variables appear statistically significant in the models are shown along with the definition of variables in the Supplementary Materials (Tables S1-S3). The data on the number of times the variables appear statistically significant in the adoption studies showed a wide variation, from 1 case (for two variables - religion and self-employment) hundreds of cases (region) a

Plot Mansger Profile

Farming Experience

Economic Risk Slope of Land

Soil Quality/Fertility

Abiotic Stress Market Access

Won-Maize crop Material Input Access

unirisos satus Distance Education Landholding Size Information Access Gender

Credit Access Household Size Oroaring

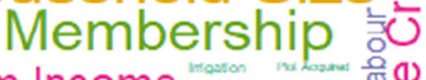

Off-Farm Income Income or Expenditure $\quad \sum$

b

Household Size

Income or Expenditure

Region Population Farming Experience

i ᄃ Membership

证 Kinship Yar Abiotic Stress

Biotic Stress

Credit Access $\frac{1}{1}$ T Training 은ivestock

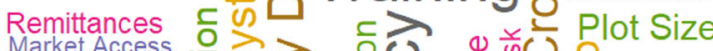
Market Access

Quality/Fertility

Marriage Status

它

음 ঠูป (1) o(1) 0 Dependency Ratio $\frac{1}{1} \amalg$ Altitude Off-Farm Income Altitude

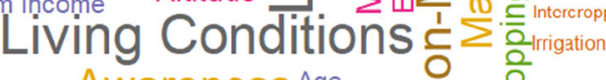

Awareness Age
Material Input Access RegionWealth

Perception on Technology

Landholding Size

Government Support

C

Perception on Technology

Material Input Access Dependency Ratio

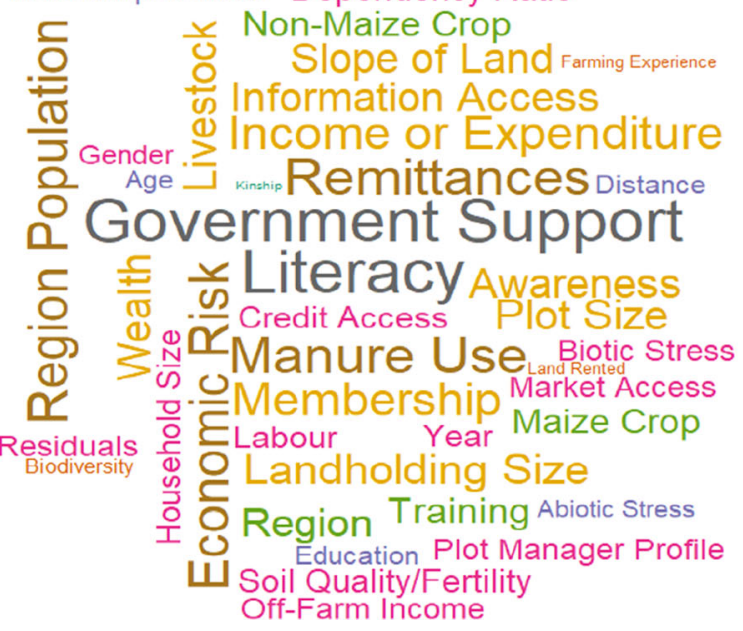


Table 3 Adoption rate and constraints of adoption for different SI technologies

\begin{tabular}{|c|c|c|c|c|}
\hline \multirow[t]{2}{*}{$\begin{array}{l}\text { Technologies examined } \\
\text { (number of models) }\end{array}$} & \multirow[t]{2}{*}{$\begin{array}{l}\text { Mean percentage share } \\
\text { of adopters (standard } \\
\text { deviation in parentheses) }\end{array}$} & \multicolumn{2}{|c|}{$\begin{array}{l}\% \text { of studies in which } \\
\text { researchers randomly } \\
\text { selected }\end{array}$} & \multirow{2}{*}{$\begin{array}{l}\text { Reasons for being excluded from } \\
\text { technology dissemination (number } \\
\text { of models in which the given factor } \\
\text { was shown to constrain technology } \\
\text { adoption) }\end{array}$} \\
\hline & & $\begin{array}{l}\text { Study areas } \\
\text { (e.g., villages) }\end{array}$ & $\begin{array}{l}\text { Sample farmers } \\
\text { from the study area }\end{array}$ & \\
\hline Improved seeds/varieties (52) & $38(21)$ & 32 & 83 & $\begin{array}{l}\text { - Farmers having limited information access }(35) \\
\text { - Technology created a bad perception among } \\
\text { farmers }(25) \\
\text { - Farms and areas where maize is a minor crop (23) }\end{array}$ \\
\hline $\begin{array}{l}\text { Conservation } \\
\text { Agriculture (14) }\end{array}$ & $25(18)$ & 43 & 93 & $\begin{array}{l}\text { - Farmers with small landholding size (9) } \\
\text { - Farmers having limited information access (8) } \\
\text { - The young age of farmers (5) } \\
\text { - Technology not suitable to adopt in farms } \\
\text { with low soil quality/fertility (5) }\end{array}$ \\
\hline $\begin{array}{l}\text { Soil and water } \\
\quad \text { conservation (29) }\end{array}$ & $23(20)$ & 14 & 100 & $\begin{array}{l}\text { - Farmers having limited information access (7) } \\
\text { - Farmers having limited group membership (7) } \\
\text { - The remoteness of the household from } \\
\text { infrastructure facilities and markets (6) } \\
\text { - Technology not suitable to adopt in plots } \\
\text { with steep slope (6) }\end{array}$ \\
\hline Chemical fertilizers (25) & $46(27)$ & 24 & 88 & $\begin{array}{l}\text { - Farmers having limited education (13) } \\
\text { - Farmers having limited information access (12) } \\
\text { - Technology not suitable to adopt in farms } \\
\text { with low soil quality/fertility (12) }\end{array}$ \\
\hline $\begin{array}{l}\text { Organic fertilizers } \\
\text { and manures (9) }\end{array}$ & $48(10)$ & 11 & 100 & $\begin{array}{l}\text { - Farmers not having livestock ( } 7 \text { ) } \\
\text { - Farmers having limited information access (4) } \\
\text { - Technology not suitable to adopt in farms } \\
\text { with low soil quality/fertility (5) }\end{array}$ \\
\hline
\end{tabular}

*Mean values were calculated from the individual studies, using sample size as the analytical weight

farm, as a binary variable) and adoption intensity (e.g., area share under the technology as a continuous variable), respectively. The most prominent determinants of adoption probability are literacy (62\% of models included it and showed having statistical significance), training obtained by farmers (60\%), and farmers' living conditions or their material wealth (59\%). The most prominent adoption intensity variables are literacy and government support; both are statistically significant in about $60 \%$ of the adoption models.

We can interpret the absence of these factors as the constraints in the diffusion process. For different sets of SIA technologies, the major constraints are listed in Table 3. The average adoption of technologies varied from 23 (soil and water management practices) to $48 \%$ (organic fertilizers and manures). However, these figures should be interpreted with caution; in several studies, the districts and villages with project implementation were selected purposively, and hence the findings cannot be considered representative of the region. The major constraints of adoption, as per the reviewed empirical studies, were (a) limited access to quality information, (b) small landholding size, (c) inferior soil quality/fertility, and (d) farmer characteristics (younger age, lack of education, etc.). Some of these key factors are examined below, to be considered while developing the technologies and inclusive dissemination strategies.

Limited spread of useful information. In adoption studies, lack of information access has multiple meanings: farmers' inability to access quality extension services (Husen et al. 2017), lack of social networks as the source of information (Jaleta et al. 2016), or sometimes even the lack of a mobile phone or radio in the household (Smale et al. 2014; Kathage et al. 2016). In several of the studies reviewed, for example, Adegbola and Gardebroek (2007), Makate and Makate (2019), and de Groote et al. (2016), information access was focused as being a major limiting factor of adoption. The prominence is understandable; access to information is one of the few variables used in the adoption models that can be modified through external interventions in the short run. Despite this, many studies have not assessed this variable adequately in their analysis. Information access is a highly endogenous variable. Observed farmer characteristics, such as age and education, and unobserved characteristics, such as motivation, may affect both information access and technology adoption, resulting in biased estimations in conventional regression analysis. How the relative significance of 
information access would change with the endogeneity correction is difficult to answer. Nonetheless, the existing studies have indicated that access to information is systematically low among farmers belonging to socially and economically marginalized sections of society (Krishna et al. 2019a). We could deduct from the crucial role of information access in the adoption models that there is a persistent lack of social and economic inclusion of the SIA programs in the South.

Reduced access to cultivable land. Landholding size or cultivable area owned by the farm household reflects the household's economies of scale, wealth, and ability to bear the risk. Farmers with more land can afford to experiment with innovations in one of their many parcels of land, and farm income would not reduce significantly even if the technology fails. In the literature, the effect of landholding on adoption is highly heterogeneous: the variable influences adoption positively in $32 \%$ of cases and negatively in $17 \%$. The constraint posed by the small landholding size for SIA diffusion appears to be highly context- and technology-specific. When we take individual technologies (Table 3), a small landholding size appears to be a major adoption constraint for Conservation Agriculture, possibly because of the relatively indivisible nature of the technology. Landholding size is also linked to information access. As famously noted by Feder and Slade (1986), extension agents in rural areas have been concentrating "on the well-to-do farmers, because their efforts were more likely to produce an immediate and visible impact and because wealthier farmers could offer them personal benefits (meals, accommodation, produce)" (p. 145).

\section{Excluding illiterates and those with limited schooling.} Literacy - a farmer's ability to read and write - is a binary variable that assesses a household's human capital. A similar effect is captured by education, often a continuous variable measuring the number of years of formal schooling or the respondent's highest grade. Education is more widely used in adoption studies than literacy, although literacy more frequently had a significant effect. About $62 \%$ of the time when literacy was included in the estimation resulted in positive and significant coefficients, whereas education had only a $30 \%$ significance rate (Table S3). The general assumption is that the greater the human capital possessed by a farmer (gained mainly through schooling), the more likely they seek innovation and adopt technologies (Murage et al. 2011). There are not many studies that showed education as having a negative effect on technology adoption. Education (and other human capital variables) could often be positively correlated with family wealth, credit access, and thereby the ability to obtain working capital. Literacy and level of schooling are low in smallholder farming communities of developing countries due to the labor required for housework and work for the family business (Webbink et al. 2012). Women and other marginalized sections of the farming community generally have smaller landholdings, and they tend to complete fewer years in school and have relatively lower levels of literacy (Boissiere 2004). The endogeneity bias and correlations with material wealth may need to be rectified to get the precise impact of education and literacy on adoption. Moreover, specifying literacy as a binary variable is often inadequate for representing the human capital as it does not indicate how well the respondent can read, write, or communicate.

Mostly, farmers who are well educated and have a sizeable plot of land, and belong to socially non-marginalized groups, adopt first and thereby reap a greater proportion of the economic rent from innovation adoption (also known as Schumpeterian rents, which are temporarily available to early adopters of technology). This phenomenon might result in increased economic inequality in rural areas and prevent achieving the stated goals of R\&D interventions such as poverty reduction. How can we ensure that diffusion of the technology does not exclude the socially and economically marginalized? Targeting can be a powerful tool to help researchers and extension agents avoid the accumulation of Schumpeterian rents through framing effective and inclusive scaling strategies. Several studies (e.g., Carter et al. 2019, Koppmair et al. 2017, Ricker-Gilbert and Jones 2015) have shown that a temporary subsidy for technologies aimed at agricultural production and storage could create a lasting impact on adoption. Purposive selection of farmers from the marginalized sections of agrarian society for providing technical training also is an effective instrument for targeted development (Van den Berg and Jiggins 2007). Government subsidies also ensure high rates of adoption through nudging and removing the constraint of working capital (Fisher and Kandiwa 2014). These factors reflect the relevance of trusted institutional backing in fostering agrarian development. To contribute to the literature on inclusive development, adoption studies need to incorporate the social dimension of technological change explicitly, strive to address the unique problems faced by the marginalized, and devise and test novel targeting strategies.

The dimension of social and economic inclusion in the technology diffusion process has been addressed only rarely in the adoption literature, despite its high relevance in the R\&D initiatives. The notion of inclusive development is becoming increasingly popular in both academic and policy circles, especially with Agenda 21 and the Sustainable Development Goals (SDGs) (United Nations 2017). The small set of studies includes Ghimire and Huang (2015), which examined the effect of household wealth on the intensity of adoption and the use of improved maize varieties in Nepal. Similarly, Langyintuo and Mungoma (2008) estimated adoption models for improved, high yielding maize varieties after stratifying households into poor- and well-endowed groups based on their access to productive assets. With respect to gender analysis, adoption decisions were examined against 
gendered roles and responsibilities by Theriault et al. (2017), Fisher and Carr (2015), Murage et al. (2015), and Ndiritu et al. (2014) in SSA. Most of these studies, however, did not question the implicit assumption taken up by the R\&D projects that SIA technologies are beneficial to all farm households, irrespective of their social and economic status. However, the yield-enhancing technologies in agriculture need not always be instrumental in accomplishing poverty reduction. According to Lowder et al. (2016), most of the 570 million farms in the world are small, and the average farm size in most low-income countries decreased during 1960-2000. Gassner et al. (2019) argued that the small size of land available to several of these households limits the amount of increase in the per capita agricultural income through technology adoption, in order to allow people to move out of poverty. According to Harris and Orr (2014), several of these technologies are only advantageous to farm households with an adequate financial and natural resource base. Dorward (2009) criticized the productivity-focused R\&D strategy of agricultural projects as highly ineffective in accomplishing rural development. Mausch et al. (2018) argued that a greater understanding of poor smallholders' aspirations is required for inclusive development. However, targeting the poor is not confined to technology development/dissemination, and policies and programs also need to implement a stronger emphasis on providing an enabling environment for smallholders to change. More theoretical and methodological research is needed in this connection.

Another limitation of the current body of literature on adoption estimation is that it relies excessively on quantitative models and is largely incapable of facilitating a clear understanding of the complex social context against which technology dissemination takes place. This aspect is further explored in the next sub-section.

\subsection{The scope and limitations of the current approach to studying SIA adoption}

Feder et al. (1985) outlined the conventional methodology of adoption studies, which consists of the representation of adoption decision with a binary variable, selecting a number of potential explanatory variables, and testing the statistical relevance of each of these variables with logistic or probit regression models. Even three decades after the publication of this seminal review paper, the approach of adoption studies in the agricultural field has not changed significantly. Technological changes are still depicted by relatively simple farmer choice that can be represented by a dichotomous variable, often overlooking the dynamic learning process and preferences of farmers that are shaped by their sociocultural context (Krishna et al. 2019b). Many adoption studies inherently assume technological change to be the replacement of old, inferior practices with new, superior ones and are for this reason inherently incapable of addressing the processes of adaptation, creolization, hybridization, and incorporation (Douthwaite et al. 2001, 2003; Glover et al. 2016). The notion that adoption is a continuous process governing the utilization of innovations (Sunding and Zilberman 2001) is crucial for developing a comprehensive analytical framework. Assessment of adoption as a continuous process requires data over a longer period, and currently, most adoption studies conducted in maize systems use cross-sectional datasets, done mostly in the context of ongoing R\&D projects. Despite the proliferation of quantitative adoption studies in agriculture and a general increase in sample size over time, this situation has remained unchanged, possibly due to the persistent desire of donors to immediately document and report the effective use of funds back to their constituencies (Krishna et al. 2019b). This has resulted in adoption studies that provide limited insights for policymakers and are inadequate to capture adoption dynamics for in-depth analysis and further improvisation of dissemination strategies in the Global South.

A large share of the empirical studies included in this review carried out adoption analysis merely as a prerequisite for impact assessment (Krishna et al. 2019b). A typical example of this genre is Lunduka et al. (2019), in which the authors examined farmer adoption of drought-tolerant maize varieties in Zimbabwe as a dichotomous variable and used this as the initial step to estimating technology impacts. While this approach has merit, these studies often are unable to provide intricate details on farmers' decision-making processes and end up overlooking the complexities of adoption decisions. Many other studies have analyzed varietal adoption relatively deeply, looking at farmer awareness and preferences as key determinants. For example, Kassie et al. (2017) recognized the importance of farmers' perceptions in determining the adoption of drought-tolerant maize varieties and estimated the average implicit price that farmers were willing to pay for drought tolerance as a varietal trait. Nevertheless, not many studies were conducted on the role of perceptions in the adoption of non-varietal technologies in maize systems. A notable exception is a study by Murage et al. (2015), which evaluated gender-specific perceptions and the extent of adoption of a climate-smart technology in SSA.

Recently, the tradeoffs and complementarities between different sustainable technologies have received significant attention. These studies captured farmer adoption of several technologies and modeled them using multivariate probit or multinomial logit models. Abay et al. (2018) and Koppmair et al. (2017) are two representative studies, which have proven the existence of strong complementarities among technologies; the policies that affect the adoption of one technology may influence (favorably or adversely) the adoption of another. Such analyses have highlighted the importance of disseminating the improved inputs and practices together as a "package" instead of promoting them in isolation. 
Socioeconomic researchers may put a greater emphasis on the lesser-studied but socially relevant aspects of technology diffusion, such as differential access to production resources and resulting economic inequalities as well as changes in sociocultural values (Albizua et al. 2019). Contrary to the widely held belief, diffusion of disembodied innovations may not always be inclusive. Furthermore, the adoption of some of the disembodied innovations requires coupling with embodied innovations (e.g., pre-emergent herbicides needed for the adoption of Conservation Agriculture). The adoption of the latter is determined by multiple binding constraints on the part of farm households and factor market imperfections (Shiferaw et al. 2015). The existing resource inequalities could affect the diffusion of agricultural innovations (Zeng et al. 2015), and more importantly, even an effective technology diffusion process could worsen the existing inequalities if not targeted.

There has been little effort made to investigate the relevance of technology attributes themselves in determining scaling-out patterns. Most of the existing adoption models focus on farmer attributes and omit the technology traits altogether (Krishna et al. 2019b). Technology fitness - the degree to which the attributes of technology favor its adoption and use-gains greater importance as technology and production systems become more complex (Douthwaite et al. 2001). Similarly, understanding the adoption problem from a system perspective is highly warranted. As observed by Glover et al. (2016), oversimplification of research problems in adoption studies to make them amenable for econometric analysis often provides an inaccurate and misleading picture for the policymakers and fellow researchers. The criticism of Conservation Agriculture studies in southern Africa by Andersson and D'Souza (2014) is valid in this connection: "Current [Conservation Agriculture] adoption studies are methodologically weak, as they are biased by the promotional project context in which they are carried out and build on farm-scale analyses of standard household surveys. [...] As contextual factors appear key influences on smallholders' farming practices, studies focusing on the wider market, institutional and policy context are also needed" (p.116).

\subsection{The potential of qualitative methodology in assessing technology change}

Most of the empirical research on the adoption of farming technologies has taken place within the disciplinary boundaries of agricultural economics, which generally relies on a quantitative toolset (Debertin and Pagoulatos 1992; Swinton 2018). The persistent scarcity of qualitative adoption studies over the last several decades has been attributed to an intense focus on validating the relationship between variables in agricultural economics (Swinton 2018). The scarcity with respect to the number of qualitative studies, however, does not correspond to their potential to assess the technological change in agrarian communities. For instance, narratives and case studies are found to have great value while assessing the success of the R\&D programs (Douthwaite et al. 2003), inclusivity in accessing technology or resource (Panta and Resurrección 2014), the outlier problem (Peiffer and Armytage 2019), etc. Through identifying the underlying reasons that are not amenable for measurement (e.g., feelings, norms), the qualitative studies help researchers obtain greater insights on observing (or, rather, not observing) the expected patterns in adoption.

This review covered the quantitative adoption studies primarily for two reasons. Firstly, several of the qualitative studies on technology change are not crop-specific; they either assess some of the system attributes (e.g., the R\&D system associated with a given technology) or invest in studying a dominant issue or theme in the agrarian society (e.g., gender inequality). Secondly, when we searched for qualitative studies conducted in cropping systems with maize as a component that had eluded our previous search, only a few new studies were found ( $n=14$; listed in Supplementary Table S4). They covered a wide array of topics and followed a diverse set of investigative approaches. For example, Place et al. (2007) focused on the role of poverty in determining the technology change, whereas Gouse et al. (2016) examined the gendered preferences behind technology adoption. As compared to most quantitative studies in maize, the qualitative ones provided a deeper understanding of the adoption process, such as partial adoption (Grabowski and Kerr 2014) and institutional factors shaping adoption (Andersson and D'Souza 2014). Most of these studies have depended on quantitative analysis, in addition to the qualitative tools, to derive insights on the adoption process, which shows that these studies did not altogether devote to a different epistemology for investigation. Nevertheless, the scarcity of qualitative studies on technology change, alongside diversity in their approaches, makes their selection a challenging assignment, which is beyond the scope of the current review. Besides, due to the small number of observations (median of 40 observations/study) and nonrandom selection of respondents, the obtained patterns cannot be generalized for the entire farming system or study region, unlike in the case of most quantitative studies.

Many of the reviewed qualitative studies generated valuable insights into the technology change in maize systems in their respective study areas. However, they fell short of a clear definition of technology and the adoption process, which is fundamental for enabling a comparison between the studies. Our review might have omitted some qualitative evaluations that did not explicitly state maize as a major component in the cropping system while detailing the technology. Qualitative studies could be made more accessible and comparable by providing greater insights on the nature of the technology and the adoption process. Systematic and rigorous use of mixed methods, which present an opportunity to gain from strengths of both qualitative and quantitative methodologies, 
would be highly advantageous (Johnson and Onwuegbuzie 2004). For example, there is a high potential to use qualitative comparative analysis (QCA) to study technology change in agriculture, especially at the meso-level (e.g., village-level) as the number of observations at this level is generally too low to establish meaningful associations quantitatively. Although the strategic relevance and practical implications of the mixed approaches are discussed widely in the literature (Bryman 2006; Creswell and Clark 2017), they are yet to gain popularity to assess technology dissemination in agriculture.

\section{Conclusion}

It is necessary to decide whether sustainable intensification is most helpfully defined only in environmental terms, or whether it should specifically incorporate a broader range of social and ethical concerns. If the former, sustainable intensification nevertheless needs to be mindful of these other concerns, and of the potential for tradeoffs and perverse outcomes. (Garnett and Godfray, 2012; page 51)

Over the last few decades, international and national public $R \& D$ investments in genetic improvement, pest management, and natural resource management have generated significant economic benefits in agrarian economies of the South (Renkow and Byerlee 2010; Adetutu and Ajayi 2020). The environmental benefits of sustainable intensification, although not commonly studied in conjunction with the economic ones, are also found substantial. The same is not true for the social dimension. Many SIA adoption studies have assumed that the social impacts of technologies are either positive or insignificant, partly due to the lack of incentives and research skillset within R\&D projects and partly due to their inability to incorporate the social and cultural factors in their empirical framework. Studies dominated by binary adoption variables lack the ability to appreciate the complexity of the dynamic adoption process and heterogeneity with respect to the adaptability of the technology to the local needs, social context, and respondents' agency. Easily observable farmer characteristics repeatedly appear as far more significant indicators of adoption than the abovementioned attributes. Furthermore, these studies fail to question the suitability of a given technology to the underlying sociocultural and agroecological realities. By exploring these issues, agricultural economists could help document SIA adoption in different systems and facilitate a better learning process.

While the current approach of empirical adoption studies is geared toward establishing and quantifying causal relationships between variables, we have observed that they undermine the importance of analyzing the complex interactions between farmer attributes, the technology attributes, and the system. The quantitative empirical analysis provides crucial information on the inter-household variations in technology adoption, following the comparative tradition of social sciences. On the other hand, the qualitative approaches would facilitate a clearer understanding of why we do observe these variations, where each case is taken as a complex entity. Although not very traditional or often used (Rabadán et al. 2020), the integrated use of both qualitative and quantitative methods could be highly beneficial. It is necessary to place more research emphasis on developing a protocol to use mixed methods to study technological changes in agriculture.

Supplementary Information The online version contains supplementary material available at https://doi.org/10.1007/s13593-020-00658-9.

Acknowledgments The authors thank Olaf Erenstein and the three anonymous reviewers of the journal for their valuable comments on the previous versions of the manuscript. We are also grateful to Ms. Liz Lucas for language editing.

\section{Compliance with ethical standards}

Funding This study received financial support from the CGIAR Research Program on Maize Agri-food Systems (CRP MAIZE; https:// maize.org/) in the form of a paid internship of the lead author (2019) and salary of the corresponding author (2019-2020). The funding agency had no other role in study design, preparation of the manuscript, and decision to publish.

Conflict of interest The authors declare that they have no conflict of interest.

Authors' contributions EJG assembled the data set, conducted the analysis, and led the writing of the paper. VVK developed the study design, participated in discussions on analysis and interpretation, contributed to writing, and revised the manuscript based on reviewers' comments.

Data availability The data will be made available in Microsoft Excel format upon request.

Code availability Not applicable.

Disclaimer The views expressed in the paper are those of the authors, and they do not necessarily reflect the views of the funding agency or the affiliated institutions.

Open Access This article is licensed under a Creative Commons Attribution 4.0 International License, which permits use, sharing, adaptation, distribution and reproduction in any medium or format, as long as you give appropriate credit to the original author(s) and the source, provide a link to the Creative Commons licence, and indicate if changes were made. The images or other third party material in this article are included in the article's Creative Commons licence, unless indicated otherwise in a credit line to the material. If material is not included in the article's Creative Commons licence and your intended use is not permitted by statutory regulation or exceeds the permitted use, you will need to obtain permission directly from the copyright holder. To view a copy of this licence, visit http://creativecommons.org/licenses/by/4.0/. 


\section{References}

Abay K, Berhane G, Seyoum A et al (2018) Estimating input complementarities with unobserved heterogeneity: evidence from Ethiopia. J Agric Econ 69:495-517. https://doi.org/10.1111/1477-9552. 12244

Abdulai AN (2016) Impact of conservation agriculture technology on household welfare in Zambia. Agric Econ 47:729-741. https://doi. org/10.1111/agec.12269

Adegbola P, Gardebroek C (2007) The effect of information sources on technology adoption and modification decisions. Agric Econ 37:5565. https://doi.org/10.1111/j.1574-0862.2007.00222.x

Adetutu MO, Ajayi V (2020) The impact of domestic and foreign R\&D on agricultural productivity in sub-Saharan Africa. World Dev 125: (in press). https://doi.org/10.1016/j.worlddev.2019.104690

Albizua A, Pascual U, Corbera E (2019) Large-scale irrigation impacts socio-cultural values: an example from rural Navarre, Spain. Ecol Econ 159:354-361. https://doi.org/10.1016/j.ecolecon.2018.12.017

Alwang J, Gotor E, Thiele G, Hareau G, Jaleta M, Chamberlin J (2019) Pathways from research on improved staple crop germplasm to poverty reduction for smallholder farmers. Agric Syst 172:16-27. https://doi.org/10.1016/j.agsy.2017.10.005

Amondo E, Simtowe F, Rahut DB, Erenstein O (2019) Productivity and production risk effects of adopting drought-tolerant maize varieties in Zambia. Int J Clim Chang Strateg Manag 11:570-591. https://doi. org/10.1108/IJCCSM-03-2018-0024

Andersson JA, D'souza S (2014) From adoption claims to understanding farmers and contexts: a literature review of conservation agriculture (CA) adoption among smallholder farmers in southern Africa. Agric Ecosyst Environ 187:116-132. https://doi.org/10.1016/j.agee.2013. 08.008

Berkson J (1944) Application to the logistic function to bio-assay. J Am Stat Assoc 39:357-365. https://doi.org/10.2307/2280041

Bliss CI (1934) The method of probits. Science (80- ) 79:38-39. https:// doi.org/10.1126/science.79.2037.38

Boissiere M (2004) Determinants of primary education outcomes in developing countries background paper for the evaluation of the World Bank's support to primary education. World Bank, Washington, D.C.

Borges J o ARB, Foletto L, Xavier VT (2015) An interdisciplinary framework to study farmers decisions on adoption of innovation: insights from expected utility theory and theory of planned behavior. African J Agric Res 10:2814-2825. https://doi.org/10.5897/ajar2015.9650

Brown B, Nuberg I, Llewellyn R (2017) Stepwise frameworks for understanding the utilisation of conservation agriculture in Africa. Agric Syst 153:11-22. https://doi.org/10.1016/j.agsy.2017.01.012

Bryman A (2006) Integrating quantitative and qualitative research: how is it done? Qual Res 6:97-113. https://doi.org/10.1177/ 1468794106058877

Bunclark L, Gowing J, Oughton E, Ouattara K, Ouoba S, Benao D (2018) Understanding farmers' decisions on adaptation to climate change: exploring adoption of water harvesting technologies in Burkina Faso. Glob Environ Chang 48:243-254. https://doi.org/10.1016/j. gloenvcha.2017.12.004

Cairns J, Prasanna BM (2018) Developing and deploying climateresilient maize varieties in the developing world. Curr Opin Plant Biol 45:226-230. https://doi.org/10.1016/j.pbi.2018.05.004

Cairns JE, Sonder K, Zaidi PH, et al (2012) Chapter one - Maize production in a changing climate: impacts, adaptation, and mitigation strategies. Advances in Agronomy 114, 1-58

Carter M, Laajaj R, Yang D (2019) Subsidies and the African Green Revolution: direct effects and social network spillovers of randomized input subsidies in Mozambique. NBER Working Paper No. 26208, National Bureau of Economic Research, Cambridge MA. https://doi.org/10.3386/w26208
CGIAR (2018) MAIZE-AFS 2018 annual technical report. CGIAR Research Program on Maize Agri-food Systems (MAIZE), Texcoco, Mexico

CGIAR Science Council (2009) Stripe review of social sciences in the CGIAR. CGIAR Science Council Secretariat, Rome

Chepchirchir RT, Macharia I, Murage AW, Midega CAO, Khan ZR (2017) Impact assessment of push-pull pest management on incomes, productivity and poverty among smallholder households in eastern Uganda. Food Secur 9:1359-1372. https://doi.org/10.1007/ s12571-017-0730-y

Creswell JW, Clark VLP (2017) Designing and conducting mixed methods research. Sage Publications, Los Angeles

Daryanto S, Wang L, Jacinthe P-A (2016) Global synthesis of drought effects on maize and wheat production. PLoS One 11:e156362. https://doi.org/10.1371/journal.pone.0156362

de Groote H, Chege CK, Tomlins K, Gunaratna NS (2014) Combining experimental auctions with a modified home-use test to assess rural consumers acceptance of quality protein maize, a biofortified crop. Food Qual Prefer 38:1-13. https://doi.org/10.1016/j.foodqual.2014. 04.014

de Groote H, Gunaratna NS, Fisher M, Kebebe EG, Mmbando F, Friesen D (2016) The effectiveness of extension strategies for increasing the adoption of biofortified crops: the case of quality protein maize in East Africa. Food Secur 8:1101-1121. https://doi.org/10.1007/ s12571-016-0621-7

de Groote H, Kimenju SC, Munyua B, et al (2020) Spread and impact of fall armyworm (Spodoptera frugiperda J.E. Smith) in maize production areas of Kenya. Agric Ecosyst Environ 292:106804. https://doi. org/10.1016/j.agee.2019.106804

Debertin DL, Pagoulatos A (1992) Research in agricultural economics 1919-1990: seventy-two years of change. Rev Agric Econ 14:1-22. https://doi.org/10.2307/1349603

Dessart FJ, Barreiro-Hurlé J, Van Bavel R (2019) Behavioural factors affecting the adoption of sustainable farming practices: a policyoriented review. Eur Rev Agric Econ 46:417-471. https://doi.org/ 10.1093/erae/jbz019

Diagne A, Demont M (2007) Taking a new look at empirical models of adoption: average treatment effect estimation of adoption rates and their determinants. Agric Econ 37:201-210. https://doi.org/10.1111/ j.1574-0862.2007.00266.x

Dorward A (2009) Integrating contested aspirations, processes and policy: development as stepping up and stepping out. Dev Policy Rev 27:131-146

Doss CR (2006) Analyzing technology adoption using microstudies: limitations, challenges, and opportunities for improvement. Agric Econ 34:207-219. https://doi.org/10.1111/j.1574-0864.2006.00119.x

Douthwaite B, Keatinge JDH, Park JR (2001) Why promising technologies fail: the neglected role of user innovation during adoption. Res Policy 30:819-836. https://doi.org/10.1016/S0048-7333(00)001244

Douthwaite B, Kuby T, Van De Fliert E, Schulz S (2003) Impact pathway evaluation: an approach for achieving and attributing impact in complex systems. Agric Syst 78:243-265. https://doi.org/10.1016/ S0308-521X(03)00128-8

Erenstein O, Kassie GT (2018) Seeding eastern Africa's maize revolution in the post-structural adjustment era: a review and comparative analysis of the formal maize seed sector. Int Food Agribus Manag Rev 21:39-52. https://doi.org/10.22434/IFAMR2016.0086

FAO (2018) Integrated management of the fall armyworm on maize: a guide for farmer field schools in Africa. Food and Agricultural Organization of the United Nations, Rome, Italy

FAO (2019) The state of food insecurity and nutrition. Food and Agricultural Organization of the United Nations, Rome, Italy 
Feder G, Just RE, Zilberman D (1985) Adoption of agricultural innovations in developing countries: a survey. Econ Dev Cult Chang 33: 255-298. https://doi.org/10.1086/451461

Feder G, Slade R (1986) The impact of agricultural extension: the training and visit system in India. World Bank Res Obs 1:139-161. https:// doi.org/10.1093/wbro/1.2.139

Fellows I (2018) CRAN: Package wordcloud. https:/cran.r-project.org/ web/packages/wordcloud/index.html

Fisher M, Carr ER (2015) The influence of gendered roles and responsibilities on the adoption of technologies that mitigate drought risk: the case of drought-tolerant maize seed in eastern Uganda. Glob Environ Chang 35:82-92. https://doi.org/10.1016/j.gloenvcha. 2015.08.009

Fisher M, Kandiwa V (2014) Can agricultural input subsidies reduce the gender gap in modern maize adoption? Evidence from Malawi. Food Policy 45:101-111. https://doi.org/10.1016/j.foodpol.2014. 01.007

Garnett T, Godfray J (2012) Sustainable intensification in agriculture: navigating a course through competing food system priorities. Food Climate Research Network and the Oxford Martin Programme on the Future of Food, University of Oxford, Oxford

Gassner A, Harris D, Mausch K, Terheggen A, Lopes C, Finlayson RF, Dobie P (2019) Poverty eradication and food security through agriculture in Africa: rethinking objectives and entry points. Outlook Agric 48:309-315. https://doi.org/10.1177/0030727019888513

Gerhart J (1975) The diffusion of hybrid maize in Western Kenya. CIMMYT, Mexico

Ghimire R, Huang W (2015) Household wealth and adoption of improved maize varieties in Nepal: a double-hurdle approach. Food Secur 7:1321-1335. https://doi.org/10.1007/s12571-015-0518-x

Gido EO, Sibiko KW, Ayuya OI, Mwangi JK (2015) Demand for agricultural extension services among small-scale maize farmers: microlevel evidence from Kenya. J Agric Educ Ext 21:177-192. https:// doi.org/10.1080/1389224X.2013.872045

Giller KE, Andersson JA, Corbeels M, Kirkegaard J, Mortensen D, Erenstein O, Vanlauwe B (2015) Beyond conservation agriculture. Front Plant Sci 6:870. https://doi.org/10.3389/fpls.2015.00870

Glover D, Sumberg J, Andersson JA (2016) The adoption problem; or why we still understand so little about technological change in African agriculture. Outlook Agric 45:3-6. https://doi.org/10.5367/ oa. 2016.0235

Glover D, Sumberg J, Ton G, Andersson J, Badstue L (2019) Rethinking technological change in smallholder agriculture. Outlook Agric 48: 169-180. https://doi.org/10.1177/0030727019864978

Godfray HCJ (2015) The debate over sustainable intensification. Food Secur 7:199-208. https://doi.org/10.1007/s12571-015-0424-2

Gouse M, Sengupta D, Zambrano P, Zepeda JF (2016) Genetically modified maize: less drudgery for her, more maize for him? Evidence from smallholder maize farmers in South Africa. World Dev 83:2738. https://doi.org/10.1016/j.worlddev.2016.03.008

Grabowski PP, Kerr JM (2014) Resource constraints and partial adoption of conservation agriculture by hand-hoe farmers in Mozambique. Int J Agric Sustain 12:37-53. https://doi.org/10.1080/14735903.2013. 782703

Greene WH (2018) Econometric analysis, 8th edn. Pearson, New York

Gunaratna NS, Moges D, de Groote H (2019) Biofortified maize can improve quality protein intakes among young children in southern Ethiopia. Nutrients 11:192. https://doi.org/10.3390/nu11010192

Gunton RM, Firbank LG, Inman A, Winter DM (2016) How scalable is sustainable intensification? Nat Plants 2:16065. https://doi.org/10. 1038/NPLANTS.2016.65

Haile MG, Wossen T, Tesfaye K, von Braun J (2017) Impact of climate change, weather extremes, and price risk on global food supply.
Econ Disasters Clim Chang 1:55-75. https://doi.org/10.1007/ s41885-017-0005-2

Harris D, Orr A (2014) Is rainfed agriculture really a pathway from poverty? Agric Syst 123:84-96. https://doi.org/10.1016/j.agsy.2013.09. 005

Husen N, Loos T, Siddig K, et al (2017) Social capital and agricultural technology adoption among Ethiopian farmers. Am J Rural Dev 5: 65-72. https://doi.org/10.12691/ajrd-5-3-2

Jaleta M, Kassie M, Tesfaye K, Teklewold T, Jena PR, Marenya P, Erenstein O (2016) Resource saving and productivity enhancing impacts of crop management innovation packages in Ethiopia. Agric Econ (United Kingdom) 47:513-522. https://doi.org/10. 1111/agec. 12251

Jayasooriya HJC, Aheeyar MMM (2016) Adoption and factors affecting on adoption of integrated pest management among vegetable farmers in Sri Lanka. Procedia Food Sci 6:208-212. https://doi. org/10.1016/j.profoo.2016.02.052

Johnson RB, Onwuegbuzie AJ (2004) Mixed methods research: a research paradigm whose time has come. Am Educ Res Asoc 33: $14-26$

Kamanga BCG, Kanyama-Phiri GY, Waddington SR, Almekinders CJM, Giller KE (2014) The evaluation and adoption of annual legumes by smallholder maize farmers for soil fertility maintenance and food diversity in central Malawi. Food Secur 6:45-59. https:// doi.org/10.1007/s12571-013-0315-3

Kassie GT, Abdulai A, Greene WH, Shiferaw B, Abate T, Tarekegne A, Sutcliffe C (2017) Modeling preference and willingness to pay for drought tolerance (DT) in maize in rural Zimbabwe. World Dev 94: 465-477. https://doi.org/10.1016/j.worlddev.2017.02.008

Kassie M, Teklewold H, Jaleta M, Marenya P, Erenstein O (2015) Understanding the adoption of a portfolio of sustainable intensification practices in eastern and southern Africa. Land Use Policy 42: 400-411. https://doi.org/10.1016/j.landusepol.2014.08.016

Kassie M, Wossen T, de Groote H, Tefera T, Sevgan S, Balew S (2020) Economic impacts of fall armyworm and its management strategies: evidence from southern Ethiopia. Eur Rev Agric Econ 47:14731501. https://doi.org/10.1093/ERAE/JBZ048

Kates RW (2011) What kind of a science is sustainability science? Proc Natl Acad Sci U S A 108:19449-19450

Kathage J, Kassie M, Shiferaw B (2016) Big constraints or small returns? Explaining nonadoption of hybrid maize in Tanzania. Appl Econ Perspect Policy 38:113-131. https://doi.org/10.1093/aepp/ppv009

Koppmair S, Kassie M, Qaim M (2017) The influence of farm input subsidies on the adoption of natural resource management technologies. Aust J Agric Resour Econ 61:539-556. https://doi.org/10. $1111 / 1467-8489.12220$

Krishna VV, Aravalath LM, Vikraman S (2019a) Does caste determine farmer access to quality information? PLoS One 14:e0210721. https://doi.org/10.1371/journal.pone.0210721

Krishna V V., Erenstein O, Sadashivappa P, et al (2014) Potential economic impact of biofortified maize in the Indian poultry sector. Int Food Agribus Manag Rev 17:123-152. https://doi.org/10.22004/ag. econ. 188712

Krishna V V., Feleke S, Marenya P, et al (2019b) A strategic framework for adoption and impact studies in the CGIAR Research Program on Maize (MAIZE). CGIAR Research Program on Maize Agri-food Systems (MAIZE), Texcoco, Mexico

Krishna VV, Qaim M, Zilberman D (2015) Transgenic crops, production risk and agrobiodiversity. Eur Rev Agric Econ 43:137-164. https:// doi.org/10.1093/erae/jbv012

Krishna VV, Yigezu YA, Karimov AA, Erenstein O (2020) Assessing technological change in agri-food systems of the Global South: a review of adoption-impact studies in wheat. Outlook Agric 49:8998. https://doi.org/10.1177/0030727020930728 
Langyintuo AS, Mungoma C (2008) The effect of household wealth on the adoption of improved maize varieties in Zambia. Food Policy 33:550-559. https://doi.org/10.1016/j.foodpol.2008.04.002

Loevinsohn MSJ, Diagne A, Whitfield S (2013) Under what circumstances and conditions does adoption of technology result in increased agricultural productivity? Protocol,. EPPI Centre, Social Science Research Unit, Institute of Education, University of London

Loos J, Abson DJ, Chappell MJ, Hanspach J, Mikulcak F, Tichit M, Fischer J (2014) Putting meaning back into "sustainable intensification." Front Ecol Environ 12:356-361. https://doi.org/10.1890/ 130157, Putting meaning back into "sustainable intensification"

Lowder SK, Skoet J, Raney T (2016) The number, size, and distribution of farms, smallholder farms, and family farms worldwide. World Dev 87:16-29. https://doi.org/10.1016/j.worlddev.2015.10.041

Lunduka RW, Mateva KI, Magorokosho C, Manjeru P (2019) Impact of adoption of drought-tolerant maize varieties on total maize production in south eastern Zimbabwe. Clim Dev 11:35-46. https://doi.org/ 10.1080/17565529.2017.1372269

Lybbert TJ, Magnan N, Spielman DJ, Bhargava AK, Gulati K (2018) Targeting technology to increase smallholder profits and conserve resources: experimental provision of laser land-leveling services to Indian farmers. Econ Dev Cult Change 66:265-306. https://doi.org/ $10.1086 / 695284$

Maddala GS (1986) Limited-dependent and qualitative variables in econometrics. Cambridge Universtiy Press, Cambridge

Mahama A, Awuni JA, Mabe FN, Azumah SB (2020) Modelling adoption intensity of improved soybean production technologies in Ghana: a generalized Poisson approach. Heliyon 6:e03543. https:// doi.org/10.1016/j.heliyon.2020.e03543

Mahon N, Crute I, Simmons E, Islam MM (2017) Sustainable intensification: "oxymoron" or "third-way"? A systematic review. Ecol Indic 74:73-97. https://doi.org/10.1016/j.ecolind.2016.11.001

Makate C, Makate M (2019) Interceding role of institutional extension services on the livelihood impacts of drought tolerant maize technology adoption in Zimbabwe. Technol Soc 56:126-133. https:// doi.org/10.1016/j.techsoc.2018.09.011

Makate C, Wang R, Makate M, Mango N (2017) Impact of drought tolerant maize adoption on maize productivity, sales and consumption in rural Zimbabwe. Agrekon 56:67-81. https://doi.org/10.1080/ 03031853.2017.1283241

Mathenge MK, Smale M, Tschirley D (2015) Off-farm employment and input intensification among smallholder maize farmers in Kenya. J Agric Econ 66:519-536. https://doi.org/10.1111/1477-9552.12093

Matuschke I, Qaim M (2008) Seed market privatisation and farmers' access to crop technologies: the case of hybrid pearl millet adoption in India. J Agric Econ 59:498-515. https://doi.org/10.1111/j.14779552.2008.00159.x

Mausch K, Harris D, Heather E, Jones E, Yim J, Hauser M (2018) Households' aspirations for rural development through agriculture. Outlook Agric 47:108-115. https://doi.org/10.1177/ 0030727018766940

Mcgowan J, Sampson M, Salzwedel DM et al (2016) Guidline statement press peer review of electronic search strategies : 2015 guideline statement. J Clin Epidemiol 75:40-46. https://doi.org/10.1016/j. jclinepi.2016.01.021

Mekuria M, Rodriguez D, Marenya P (2017) Enhancing smallholder agriculture productivity, resilience and sustainability: evidences from SIMLESA 2010-2018 end of project review and stakeholders' meeting. International Maize and Wheat Improvement Center (CIMMYT), Texcoco, Mexico

Moher D, Liberati A, Tetzlaff J, Altman DG, The PRISMA Group (2009) Preferred reporting items for systematic reviews and meta-analyses : the PRISMA statement. PLoS Med 6:e1000097. https://doi.org/10. 1371/journal.pmed.1000097
Montt G, Luu T (2020) Does conservation agriculture change labour requirements? Evidence of sustainable intensification in subSaharan Africa. J Agric Econ 71:556-580. https://doi.org/10.1111/ $1477-9552.12353$

Morris M, Mekuria M, Gerpacio R (2003) Impacts of CIMMYT maize breeding research. In: Evenson RE, Gollin D (eds) Crop variety improvement and its effect on productivity. CABI, Oxford, UK, pp $135-159$

Murage AW, Obare G, Chianu J, Amudavi DM, Pickett J, Khan ZR (2011) Duration analysis of technology adoption effects of dissemination pathways: a case of "push-pull" technology for control of Striga weeds and stemborers in Western Kenya. Crop Prot 30:531538. https://doi.org/10.1016/j.cropro.2010.11.009

Murage AW, Pittchar JO, Midega CAO, Onyango CO, Khan ZR (2015) Gender specific perceptions and adoption of the climate-smart pushpull technology in eastern Africa. Crop Prot 76:83-91. https://doi. org/10.1016/j.cropro.2015.06.014

Ndiritu SW, Kassie M, Shiferaw B (2014) Are there systematic gender differences in the adoption of sustainable agricultural intensification practices? Evidence from Kenya. Food Policy 49:117-127. https:// doi.org/10.1016/j.foodpol.2014.06.010

Ntshangase NL, Muroyiwa B, Sibanda M (2018) Farmers' perceptions and factors influencing the adoption of no-till conservation agriculture by small-scale farmers in Zashuke, KwaZulu-Natal Province. Sustain 10:1-16. https://doi.org/10.3390/su10020555

Ofori E, Griffin T, Yeager E (2020) Duration analyses of precision agriculture technology adoption: what's influencing farmers' time-toadoption decisions? Agric Financ Rev 80:647-664. https://doi.org/ 10.1108/AFR-11-2019-0121

Ouma J, Bett E, Mbataru P (2014) Drivers of adoption of improved maize varieties in moist transitional zone of eastern Kenya. J Econ Sustain Dev 5:147-156

Panta SK, Resurrección BP (2014) Gender and caste relations amidst a changing political situation in Nepal: insights from a farmermanaged irrigation system. Gend Technol Dev 18:219-247. https://doi.org/10.1177/0971852414529482

Peiffer C, Armytage R (2019) Searching for success: a mixed methods approach to identifying and examining positive outliers in development outcomes. World Dev 121:97-107. https://doi.org/10.1016/j. worlddev.2019.04.013

Pittelkow CM, Linquist BA, Lundy ME, Liang X, van Groenigen KJ, Lee J, van Gestel N, Six J, Venterea RT, van Kessel C (2015) When does no-till yield more? A global meta-analysis. F Crop Res 183:156168. https://doi.org/10.1016/j.fcr.2015.07.020

Place F, Adato M, Hebinck P (2007) Understanding rural poverty and investment in agriculture: an assessment of integrated quantitative and qualitative research in Western Kenya. World Dev 35:312-325. https://doi.org/10.1016/j.worlddev.2006.10.005

Prasanna B, Huesing JE, Eddy R, Peschke VM (2018) Fall armyworm in Africa: a guide for integrated pest management. CGIAR Research Program on Maize Agri-food Systems (MAIZE), Texcoco, Mexico

Pretty J, Bharucha ZP (2014) Sustainable intensification in agricultural systems. Ann Bot 114:1571-1596. https://doi.org/10.1093/aob/ mcu205

Rabadán A, Díaz M, Brugarolas M, Bernabéu R (2020) Why don't consumers buy organic lamb meat? A Spanish case study. Meat Sci 162: 108024. https://doi.org/10.1016/j.meatsci.2019.108024

Renkow M, Byerlee D (2010) The impacts of CGIAR research: a review of recent evidence. Food Policy 35:391-402. https://doi.org/10. 1016/j.foodpol.2010.04.006

Ricker-Gilbert J, Jones M (2015) Does storage technology affect adoption of improved maize varieties in Africa? Insights from Malawi's input subsidy program. Food Policy 50:92-105. https://doi.org/10. 1016/j.foodpol.2014.10.015 
Rogers EM (1962) Diffusion of innovations, 3rd edn. The Free Press, New York

Rohrer JM, Brümmer M, Schmukle SC, Goebel J, Wagner GG (2017) "What else are you worried about?" Integrating textual responses into quantitative social science research. PLoS One 12:e182156. https://doi.org/10.1371/journal.pone.0182156

Shiferaw B, Kebede T, Kassie M, Fisher M (2015) Market imperfections, access to information and technology adoption in Uganda: challenges of overcoming multiple constraints. Agric Econ 46:475488. https://doi.org/10.1111/agec.12175

Shiferaw B, Prasanna BM, Hellin J, Bänziger M (2011) Crops that feed the world 6. Past successes and future challenges to the role played by maize in global food security. Food Secur 3:307-327. https://doi. org/10.1007/s12571-011-0140-5

Sinyolo S (2020) Technology adoption and household food security among rural households in South Africa: the role of improved maize varieties. Technol Soc 60:101214. https://doi.org/10.1016/j.techsoc. 2019.101214

Smale M, Birol E, Asare-Marfo D (2014) Smallholder demand for maize hybrids in Zambia : how far do seed subsidies reach ? J Agric Econ 65:349-367. https://doi.org/10.1111/1477-9552.12046

Snapp SS, Grabowski P, Chikowo R, Smith A, Anders E, Sirrine D, Chimonyo V, Bekunda M (2018) Maize yield and profitability tradeoffs with social, human and environmental performance: is sustainable intensification feasible? Agric Syst 162:77-88. https:// doi.org/10.1016/j.agsy.2018.01.012

Struik PC, Kuyper TW (2017) Sustainable intensification in agriculture: the richer shade of green. A review Agron Sustain Dev 37:39. https://doi.org/10.1007/s13593-017-0445-7

Sunding D, Zilberman D (2001) The agricultural innovation process: research and technology adoption in a changing agricultural sector. In: Gardner BL, Rausser GC (eds) Handbook of agricultural economics (vol 1). Elsevier Science B.V, Amsterdam, The Netherlands, pp 207-261

Swinton SM (2018) Why should I believe your applied economics? Am J Agric Econ 100:381-391. https://doi.org/10.1093/ajae/aax096

Tambo JA, Mockshell J (2018) Differential impacts of conservation agriculture technology options on household income in sub-Saharan Africa. Ecol Econ 151:95-105. https://doi.org/10.1016/j.ecolecon. 2018.05.005

Tanumihardjo SA, McCulley L, Roh R, Lopez-Ridaura S, Palacios-Rojas N, Gunaratna NS (2020) Maize agro-food systems to ensure food and nutrition security in reference to the sustainable development goals. Glob Food Sec 25:100327. https://doi.org/10.1016/j.gfs. 2019.100327

Tesfaye K, Kruseman G, Cairns JE, Zaman-Allah M, Wegary D, Zaidi PH, Boote KJ, Rahut D, Erenstein O (2018) Potential benefits of drought and heat tolerance for adapting maize to climate change in tropical environments. Clim Risk Manag 19:106-119. https://doi. org/10.1016/j.crm.2017.10.001

Theriault V, Smale M, Haider H (2017) How does gender affect sustainable intensification of cereal production in the west African Sahel?
Evidence from Burkina Faso. World Dev 92:177-191. https://doi. org/10.1016/j.worlddev.2016.12.003

Tobin J (1958) Estimation of relationships for limited dependent variables. Econometrica 26:24-36. https://doi.org/10.2307/1907382

United Nations (2017) The sustainable development goals report. https:// unstats.un.org/sdgs/?aspxerrorpath=/sdgs/files/report/2017/ TheSustainableDevelopmentGoalsReport2017.pdf.

Van den Berg H, Jiggins J (2007) Investing in farmers-the impacts of farmer field schools in relation to integrated pest management. World Dev 35:663-686. https://doi.org/10.1016/j.worlddev.2006. 05.004

Vommi HK, LaVergne DD, Gartin SA (2013) Growers' perceptions and adoption practices of integrated pest management in West Virginia. J Ext 51:2RIB

Wainaina P, Tongruksawattana S, Qaim M (2016) Tradeoffs and complementarities in the adoption of improved seeds, fertilizer, and natural resource management technologies in Kenya. Agric Econ 47: 351-362. https://doi.org/10.1111/agec.12235

Webbink E, Smits J, de Jong E (2012) Hidden child labor: determinants of housework and family business work of children in 16 developing countries. World Dev 40:631-642. https://doi.org/10.1016/j. worlddev.2011.07.005

Willock J, Deary IJ, Edwards-Jones G, Gibson GJ, McGregor MJ, Sutherland A, Dent JB, Morgan O, Grieve R (1999) The role of attitudes and objectives in farmer decision making: business and environmentally-oriented behaviour in Scotland. J Agric Econ 50: 286-303. https://doi.org/10.1111/j.1477-9552.1999.tb00814.x

Wooldridge JM (2003) Further results on instrumental variables estimation of average treatment effects in the correlated random coefficient model. Econ Lett 79:185-191. https://doi.org/10.1016/S01651765(02)00318-X

Wooldridge JM (2020) Introductory econometrics: a modern approach, 7 th edn. Cengage, Boston

Wossen T, Abdoulaye T, Alene A, Feleke S, Menkir A, Manyong V (2017) Measuring the impacts of adaptation strategies to drought stress: the case of drought tolerant maize varieties. J Environ Manag 203:106-113. https://doi.org/10.1016/j.jenvman.2017.06. 058

Yap VY, Neergaard A, Bruun TB (2017) 'To adopt or not to adopt?' Legume adoption in maize-based systems of northern Thailand: constraints and potentials. L Degrad Dev 28:731-741. https://doi. org/10.1002/ldr.2546

Zeng D, Alwang J, Norton GW, Shiferaw B, Jaleta M, Yirga C (2015) Ex post impacts of improved maize varieties on poverty in rural Ethiopia. Agric Econ 46:515-526. https://doi.org/10.1111/agec. 12178

Zopounidis C, Doumpos M (2002) Multicriteria classification and sorting methods: a literature review. Eur J Oper Res 138:229-246. https:// doi.org/10.1016/S0377-2217(01)00243-0

Publisher's note Springer Nature remains neutral with regard to jurisdictional claims in published maps and institutional affiliations. 